\title{
STATE WITHDRAWAL NOTIFICATIONS FROM THE ROME STATUTE OF THE INTERNATIONAL CRIMINAL COURT: SOUTH AFRICA, BURUNDI AND THE GAMBIA
}

\begin{abstract}
In 2016 three African states namely South Africa, Burundi and The Gambia submitted written notifications of withdrawal from the Rome Statute of the International Criminal Court (Rome Statute) to the Secretary-General of the United Nations pursuant to Article 127 of the Rome Statute. Although the African Union welcomed and fully supported the three withdrawal notifications and considered them as 'pioneer implementers' of its 'Withdrawal Strategy', The Gambia and South Africa withdrew their notifications of withdrawal. Some other states - Kenya, Namibia and Uganda - have made threats to submit withdrawal notifications. This article examines four issues arising out of the said withdrawal notifications. First, why did the three states submit withdrawal notifications from the Rome Statute? Second, what is the impact of the three states' withdrawal notifications? Third, is the African Court on Human and Peoples' Rights (or the yet-to-be-established African Court of Justice and Human and Peoples' Rights) a suitable African regional 'alternative' to the ICC? Finally, what steps might be taken to avoid, or at least minimise, further withdrawals in the future and to avoid impunity of perpetrators of international crimes in states that have withdrawn from the Rome Statute?
\end{abstract}

\section{INTRODUCTION}

In recent years the growing discontent with the perceived unequal application of the Rome Statute of the International Criminal Court (Rome Statute), ${ }^{1}$ the founding treaty of the International Criminal Court (ICC), particularly among some African leaders, culminated in

\footnotetext{
* Professor of International Law and Human Rights, Brunel Law School, Brunel University London. E-mail: manisuli.ssenyonjo@brunel.ac.uk.

${ }^{1}$ Rome Statute of the International Criminal Court (adopted 17 July 1998, entered into force 1 July 2002) 2187 UNTS 3.
} 
3 state withdrawal notifications out of 124 state parties. ${ }^{2}$ In October and November 2016, three African Union (AU) member state parties to the Rome Statute - The Republic of South Africa (South Africa), ${ }^{3}$ the Republic of Burundi (Burundi) ${ }^{4}$ and The Republic of The Gambia (The Gambia) $)^{5}$ - submitted their written notifications of withdrawal from the Rome Statute to the United Nations (UN) Secretary General. ${ }^{6}$ This was done in accordance with Article 127(1) of the Rome Statute, which provides that a state party to the Rome Statute may withdraw from the Statute 'by written notification addressed to the Secretary-General of the United Nations'. ${ }^{7}$ The notifications of withdrawals were welcomed and supported by the African Union (AU) as part of the AU's 'Withdrawal Strategy' from the Rome Statute. ${ }^{8}$ However, both The Gambia and South Africa withdrew their notifications of withdrawal before they became effective. At present, this signals their renewed commitment to the Rome Statute. Unless Burundi also withdraws its notification of withdrawal at any time before it becomes effective, its withdrawal shall take effect one year after the date of receipt by the UN Secre-

\footnotetext{
${ }^{2}$ Assembly of States Parties, States Parties to the Rome Statute, https://asp.icccpi.int/en_menus/asp/states $\% 20$ parties/Pages/the $\% 20$ states $\% 20$ parties $\% 20$ to $\%$ 20 the $\% 20$ rome $\% 20$ statute.aspx. For recent literature on the ICC and Africa see generally KM Clarke et al. (eds), Africa and the ICC: Perceptions of Justice (Cam bridge University Press, 2016); EA Ankumah (ed), The International Criminal Court and Africa: One Decade On (Intersentia, 2016); and J Nyawo, Selective Enforcement and International Criminal Law: The International Criminal Court and Africa (Inter sentia, 2017).

${ }^{3}$ South Africa deposited its instrument of ratification to the Rome Statute on 27 November 2000.

${ }^{4}$ Burundi deposited its instrument of ratification to the Rome Statute on 21 September 2004.

${ }^{5}$ The Gambia deposited its instrument of ratification to the Rome Statute on 28 June 2002.

${ }^{6}$ The official notifications of withdrawal were received by the UN secretary General on 19 October 2016 for South Africa, 27 October 2016 for Burundi, and 10 November 2016 for The Gambia. See the following Withdrawal Depository Notifications: C.N.786.2016.TREATIES-XVIII.10 (South Africa); C.N.805.2016.TREATIESXVIII.10 (Burundi) and C.N.862.2016.TREATIES-XVIII.10 (The Gambia).

${ }^{7}$ For a commentary on Art 127 see Roger S Clark, 'Article 127: Withdrawal' in O Triffterer and K Ambos (eds), Rome Statute of the International Criminal Court: A Commentary, 3rd edn (CH Beck, Hart, Nomos, 2016) 2322-2324.

${ }^{8}$ Decision on the International Criminal Court Doc. EX.CL/1006(XXX), Assembly/AU/Draft/Dec.1(XXVIII)Rev.2 (30-31 January 2017) para 8; African Union (AU), Withdrawal Strategy Document (2017, on file with author).
} 
tary-General. ${ }^{9}$ This will make Burundi the first state party to the Rome Statute in the world to withdraw from the Rome Statute, 15 years since the Statute entered into force.

South Africa, one of the first signatories to the Rome Statute, ${ }^{10}$ ratified the Rome Statute on 27 November 2000 after first obtaining parliamentary approval. ${ }^{11}$ In order to ensure the effective implementation of the Rome Statute in South Africa, in accordance with the South African Constitution, a domestic statute was enacted through the Implementation of the Rome Statute of the International Criminal Court 2002. ${ }^{12}$ This made South Africa the first African state to domesticate the Rome Statute. On 19 October 2016, the government of South Africa Minister of International Relations and Cooperation, acting for the executive and without seeking or receiving prior approval of the South African parliament or any public consultation, ${ }^{13}$ unilaterally submitted to the UN Secretary General a notification of South Africa's withdrawal from the Rome Statute. ${ }^{14}$ This was followed by a Parliamentary Bill to repeal the Implementation of the Rome Statute in South Africa. ${ }^{15}$

\footnotetext{
${ }^{9}$ Rome Statute, Art 127(1). Unless Burundi's withdrawal notification is withdrawn, it shall take effect on 27 October 2017.

${ }^{10}$ South Africa signed the Rome Statute on 17 July 1998 (the date it was first opened for signature).

${ }^{11}$ Constitution of the Republic of South Africa 1996, Section 231(2), provides that an 'international agreement binds the Republic only after it has been approved by resolution in both the National Assembly and the National Council of Provinces'; Glenister v President of the Republic of South Africa and Others (CCT 48/10) [2011] ZACC 6, para 89 Ngcobo CJ.

${ }^{12}$ Act 27 of 2002, adopted by Parliament in 2002, http://www.gov.za/sites/www. gov.za/files/a27-02.pdf; Glenister (n 11), para 95; National Commissioner of the South African Police Service v Southern African Human Rights Litigation Centre and An other (CCT 02/14), [2014] ZACC 30; Constitution of the Republic of South Africa 1996, Section 231(4): 'Any international agreement becomes law in the Republic when it is enacted into law by national legislation...'.

${ }^{13}$ Constitution of the Republic of South Africa 1996, Section 231(2) (n 10). By implication even withdrawal notification from an international agreement like the Rome Statute must follow the procedure in Section 231(2) - it must be submitted 'after it has been approved by resolution in both the National Assembly and the National Council of Provinces'.

${ }^{14}$ See UN, South Africa: Withdrawal, C.N.786.2016.TREATIES-XVIII.10.

${ }^{15}$ Implementation of the Rome Statute of the International Criminal Court Act Repeal Bill, 2016, http://www.parliament.gov.za/live/commonrepository/Processed/ 20161111/616356_1.pdf.
} 
Although South Africa's withdrawal notification was revoked on 7 March 2017 in order to adhere to a High Court judgment, ${ }^{16}$ it is still useful to understand events leading to South Africa's notification of withdrawal, which came after three significant recent developments. First, in June 2015, the High Court of South Africa, Gauteng Division, Pretoria, ordered the South African government to prohibit the President of the Republic of Sudan, Omar Hassan Ahmad Al Bashir (Al Bashir), who is subject to two ICC arrest warrants, ${ }^{17}$ from leaving South Africa, which the South African government ignored. ${ }^{18}$ The Supreme Court of Appeal of South Africa found that South Africa's failure to take steps to arrest and detain, for surrender to the ICC, Al Bashir, after his arrival in South Africa on 13 June 2015 to attend the 25th AU Assembly, was inconsistent with South Africa's obligations under the Rome Statute. ${ }^{19}$ The ICC Pre-Trial Chamber II had earlier made it clear that ICC State parties including South Africa are under an obligation to arrest and surrender Al Bashir to the ICC. ${ }^{20}$ Second, the AU (which

${ }^{16}$ See Democratic Alliance v Minister of International Relations and Cooperation and Others, Case No 83145/2016 (High Court of South Africa, 22 February 2017), http://saflii.org/za/cases/ZAGPPHC/2017/53.pdf, declaring the notice of with drawal, without prior parliamentary approval, 'unconstitutional and invalid'.

${ }^{17}$ See Pre-Trial Chamber I, 'Warrant of Arrest for Omar Hassan Ahmad Al Bashir', ICC-02/05-01/09-1, 4 March 2009 (warrant for seven counts of war crimes and crimes against humanity); Pre-Trial Chamber I, 'Second Warrant of Arrest for Omar Hassan Ahmad Al Bashir', ICC- 02/05-01/09-95, 12 July (warrant for three counts of genocide).

${ }^{18}$ Southern Africa Litigation Centre v Minister of Justice And Constitutional Development and Others, Case No 27740/2015, 2015 (9) BCLR 1108 (GP) (24 June 2015), http://saflii.org/za/cases/ZAGPPHC/2015/402.html.

19 The Minister of Justice and Constitutional Development $v$ The Southern African Litigation Centre (867/15) [2016] ZASCA 17 (15 March 2016). The Supreme Court of Appeal's decision in this case is final since on 18 November 2016, the Constitutional Court of South Africa issued a direction noting South Africa's withdrawal of its appeal to the Constitutional Court, The Minister of Justice and Constitutional Development and Others $v$ The Southern African Litigation Centre and Others, CCT $75 / 16$.

${ }^{20}$ The Prosecutor v Omar Hassan Ahmad Al Bashir, Decision following the Prosecutor's request for an order further clarifying that the Republic of South Africa is under the obligation to immediately arrest and surrender Omar Al Bashir, ICC-02/ 05-01/09-242, 13 June 2015; The Prosecutor v Omar Hassan Ahmad Al Bashir, Decision on the Cooperation of the Democratic Republic of the Congo Regarding Omar Al Bashir's Arrest and Surrender to the Court, ICC-02/05-01/09-195, 9 April 2014, paras 28-31. 
has more than a third of member states as non-parties to the Rome Statute), ${ }^{21}$ had made several decisions calling upon African States not to cooperate with the $\mathrm{ICC}^{22}$ and urged its member states to consider 'collective withdrawal from the ICC'. ${ }^{23}$ Third, South Africa's withdrawal notification came after the withdrawal process initiated by Burundi ${ }^{24}$ and later supported by The Gambia. ${ }^{25}$

This article examines key issues in connection with the three withdrawal state notifications. Section II examines reasons for withdrawal notifications. It considers why did the three states submit notifications of withdrawal from the Rome? Section III analyses the likely consequences of the 3 withdrawal notifications from the Rome Statute. Section IV considers whether the African Court on Human and Peoples' Rights (or the future African Court of Justice and Human and Peoples' Rights) is a suitable African regional alternative or complementary to the ICC. Section V makes concluding observations. It comments on whether the three withdrawing states should consider withdrawing the withdrawal notifications and outlines measures that might be taken to avoid, or at least minimise, further withdrawals in the future and to avoid impunity of perpetrators of international crimes in states that have withdrawn from the Rome Statute.

${ }^{21} 34$ out of $54 \mathrm{AU}$ member states (62 per cent) were parties to the Rome Statute in December 2016, making African states the largest block of state parties to the Rome Statute.

${ }^{22}$ See e.g. the following AU decisions on the ICC: Assembly/AU/Dec.245(XIII), 3 July 2009, para 10; Assembly/AU/Dec.296(XV), 27 July 2010, para 5; Assembly/AU/ Dec.397(XVIII), 30 January 2012, paras 6 and 8.

${ }^{23}$ See Decision on the International Criminal Court - Doc. EX.CL/952(XXVIII), AU Assembly/AU/Dec 590 (XXVI) 30-31 January 2016, para 10(iv).

${ }^{24}$ See Government of Burundi, Press Release of the Meeting of Council of Ministers of Thursday, October 6, 2016, http://www.burundi.gov.bi/spip.php?arti cle1534. On 12 October 2016, the Burundian Parliament voted in favour of Burundi's withdrawal from the Rome Statute and on 18 October 2016, President Pierre Nku runziza of Burundi signed off the bill for Burundi's withdrawal from the ICC, after the ICC Prosecutor Fatou Bensouda opened a preliminary examination in April 2016 into possible crimes against humanity allegedly committed in Burundi since April 2015. See also UN Depository Notification, Burundi: Withdrawal, C.N.805. 2016.TREATIES-XVIII.10, 27 October 2016.

${ }^{25}$ See UN Depository Notification, Gambia: Withdrawal, C.N.862.2016.TREATIES-XVIII.10, 11 November 2016. 


\section{REASONS FOR WITHDRAWAL NOTIFICATIONS FROM THE ROME STATUTE}

Article 127 of the Rome Statute which applies to withdrawals from the Statute does not require states to provide any reason for withdrawing. It follows, therefore, that a state party to the Rome Statute may submit a withdrawal notice from the Statute at any time, in accordance with Article 127, without giving any reason, 'good or 'bad'. ${ }^{26}$ While withdrawal notifications of Burundi and The Gambia did not state any specific reason(s) for withdrawing, it is possible to infer some reasons from the prevailing circumstances in both states before withdrawal notifications were submitted. South Africa decided to give reasons for its withdrawal. ${ }^{27}$ An analysis of the reasons advanced by South Africa is helpful in understanding why it took this step and what needs to be done to avoid further possible withdrawal notifications in the future by any other state sharing the same views as South Africa. In what follows, an analysis is made of the reasons that principally motivated the three withdrawal notifications.

\subsection{Avoiding Accountability before the ICC for Possible International Crimes}

Both withdrawal notifications of Burundi and The Gambia were intended to ensure that state officials including sitting heads of state President Pierre Nkurunziza of Burundi since 2005 and President Yahya Jammeh of The Gambia from 1994 to 19 January 2017 escape possible criminal investigations and prosecutions before the ICC. Burundi experienced violence before and after legislative and presidential elections since April 2015 including a failed coup de tat in May 2015. The government responded by carrying out several operations leading to gross violations of human rights possibly amounting to crimes against humanity of 'killing, other inhumane acts, imprisonment, torture, rape and other sexual violence, as well as cases of enforced disappearances and acts of persecution'. ${ }^{28}$ Thus, on

\footnotetext{
${ }^{26}$ Clark (n 7), 2322.

${ }^{27}$ See Declaratory Statement by the Republic of South Africa on the Decision to Withdraw from the Rome Statute of the International Criminal Court, C.N.786.2016.TREATIES-XVIII.10 (19 October 2016), https://treaties.un.org/doc/ Publication/CN/2016/CN.786.2016-Eng.pdf.

${ }^{28}$ ICC, The Office of the Prosecutor, Report on Preliminary Examination Activities 2016, 14 November 2016, https://www.icc-cpi.int/iccdocs/otp/161114-otp-rep-PE_ ENG.pdf, paras 36, 39-52.
} 
25 April 2016, the ICC Prosecutor opened a preliminary examination of the situation in Burundi since April 2015. On 20 September 2016, the UN Independent Investigation on Burundi found that 'gross human rights violations have taken place and are taking place, committed primarily by State agents and those linked to them'. ${ }^{29}$ The Commission added that these violations were widespread, 'systematic and patterned and impunity [was] pervasive'. ${ }^{30}$ The Commission expressed the view that some of the violations could amount to crimes against humanity and that independent international processes determine accountability for possible international crimes'. ${ }^{31}$ Following these findings, the UN Human Rights Council decided, on 30 September 2016, to create for a period of one year a commission of inquiry into human rights abuses in Burundi since April 2015 that would identify alleged perpetrators of human rights violations in Burundi with a view to ensuring full accountability. ${ }^{32}$

Burundi's head of state and other state officials did not want the Prosecutor to proceed with the preliminary examination because they would be possibly identified among the alleged perpetrators. At the time 'more than 430 persons had reportedly been killed, at least 3,400 people arrested and over 230,000 Burundians forced to seek refuge in neighbouring countries'. ${ }^{33}$ The preliminary examination focussed on acts of killing, imprisonment, torture, rape and other forms of sexual violence, as well as cases of enforced disappearances that have been allegedly committed since April 2015 in Burundi. ${ }^{34}$ It should be noted that a full investigation can still be carried out since withdrawal has no impact on withdrawing state obligations (to cooperate with the Court in connection with criminal investigations and proceedings) under the Rome Statute prior to the date on which the withdrawal

${ }^{29}$ Report of the United Nations Independent Investigation on Burundi (UNIIB) established pursuant to Human Rights Council resolution S-24/1, UN Doc A//HRC/ 33/37, 20 September 2016, 1.

${ }^{30}$ Ibid.

${ }^{31}$ Ibid., paras 123-124.

${ }^{32}$ Human Rights Council, Human Rights Situation in Burundi, UN Doc A/HRC/ 33/L.31, 27 September 2016. See also African Commission Resolution on the Human Rights Situation in the Republic of Burundi, ACHPR/Res.357(LIX) 2016, 4 November 2016.

${ }^{33}$ ICC, Preliminary Examination: Burundi, https://www.icc-cpi.int/burundi.

${ }^{34}$ Ibid. 
becomes effective. ${ }^{35}$ However, it would be very difficult for the Prosecutor to obtain Burundi's cooperation with the investigations.

For The Gambia President Jammeh was concerned that the situation in The Gambia could potentially be subjected to a preliminary investigation by the ICC. Jammeh took power in a coup in 1994 but lost an election on 1 December 2016. ${ }^{36}$ This happened shortly after submission of The Gambia's notice of withdrawal from the Rome Statute. Jammeh's government 'frequently committed serious human rights violations including arbitrary detention, enforced disappearance, and torture against those who expressed opposition to the government' especially in the aftermath of the 30 December 2014 attempted coup. ${ }^{37}$ These could amount to crimes against humanity. The Gambia under President Jammeh consistently demonstrated its lack of commitment to accountability before judicial and quasi-judicial bodies. For example, it refused to implement three legally binding decisions by the Court of Justice of the Economic Community of West African States (ECOWAS Court) regarding the torture, ${ }^{38}$ murder $^{39}$ and enforced disappearance of journalists, ${ }^{40}$ and it has on several occasions failed to cooperate with the resolutions of the African Commission on Human and Peoples' Rights, which is

\footnotetext{
${ }^{35}$ Rome Statute, Art 127(2); Vienna Convention on the Law of Treaties (1980) 1155 UNTS 331, Art 70(1)(b).

${ }^{36}$ The Gambian Independent Electoral Commission (IEC) declared that Barrow obtained 222,708 votes (43.3 percent) while Jammeh obtained 208,487 (39.6 percent). See IEC, The Total of Final Results, 5 December 2016, at http://iec.gm/the-total-offinal-election-results/.

${ }^{37}$ Human Rights Watch, World Report 2016: Gambia, https://www.hrw.org/ world-report/2016/country-chapters/gambia; European Parliament Resolution of 12 May 2016 on The Gambia (2016/2693(RSP)).

${ }^{38}$ See Musa Saidykhan v Republic of The Gambia, Suit NO ECW/CCJ/APP/11/07, Judgment No ECW/CCJ/JUD/08/10 (6 December 2010) concerning the award of damages in the sum of USD 200,000 for arrest, detention and torture of journalist Musa Saidykhan for 22 days without any lawful excuse and without trial.

${ }^{39}$ See Deyda Hydara Jr. and Others v The Gambia, Case No ECW/CCJ/APP/30/ 11 (10 June 2014), the ECOWAS Court awarded damages of US $\$ 50,000$ for the prejudice suffered as a result of the government's failure to conduct effective and impartial investigations into the assassination of Deyda Hydara (former publisher and editor of the Banjul-based newspaper The Point, and former president of the Gambian Press Union) leading to culture of impunity in the Gambia.

${ }^{40}$ See Chief Ebrimah Manneh $v$ The Republic of The Gambia, Suit No ECW/CCJ/ APP/04/07, Judgment No ECW/CCJ/JUD/03/08 (5 June 2008). The ECOWAS Court ordered The Gambia to immediately release journalist Manneh and pay damages in the sum of USD100 000 to Manneh or, in his absence, to his family.
} 
based in Banjul, The Gambia. ${ }^{41}$ Its withdrawal notification was a clear manifestation of its unwillingness to be subjected to a possible ICC investigation.

Nevertheless, it might still be possible to investigate the situation in The Gambia since President Jammeh lost an election in December 2016 to Adama Barrow. ${ }^{42}$ Since Jammeh was forced to carry out 'a peaceful and orderly transition process, and to transfer power to President-elect Adama Barrow' in January 2017 in accordance with the Gambian Constitution, ${ }^{43}$ Barrow indicated that he would withdraw the notification to withdrawal The Gambia from the Rome Statute since there is no need for us [The Gambia] to leave the ICC'. ${ }^{44}$ Given that the withdrawal notification was an executive decision made without prior parliamentary approval or any public consultation, it can be withdrawn by an executive act at any time before it becomes effective.

Since the new government of The Gambia has expressed commitment to the rule of law and accountability, in February 2017 it notified the UN Secretary General of 'its decision to rescind' the

${ }^{41}$ See eg, African Commission, Resolution on the Human Rights Situation in the Republic of The Gambia, Doc ACHPR/Res.134 (XXXXIIII) 2008 adopted at the Commission's 44th Ordinary Session, Abuja, Nigeria, 10-24 November 2008; Resolution on the Deteriorating Human Rights Situation in The Gambia, adopted at the Commission's 7th extraordinary session, Dakar, Senegal, 11 October 2009, http:// www.achpr.org/sessions/7th-eo/resolutions/145/.

${ }^{42}$ UN News Centre, 'Gambia: UN Calls on Outgoing President to Respect Election Results and to Carry Out a Peaceful Transition', 10 December 2016, http:// www.un.org/apps/news/story.asp?NewsID $=55776 \#$.WE2k2j5vjIU.

${ }^{43}$ See UN Security Council, Presidential Statement: Gambian Leaders Must Respect Vote Result, S/PRST/2016/19, https://www.un.org/press/en/2016/sc12650. doc.htm; UN Security Council Resolution 2337, S/RES/2337 (19 January 2017) para 7; Joint Declaration by the Economic Community of West African States, the Afri can Union and the United Nations on the Political Situation of the Islamic Republic of The Gambia on 21 January 2017, http://www.peaceau.org/uploads/ecowas-au-unjoint-communique.pdf.

${ }^{44}$ K Cham, 'The Gambia's New President to "Reverse ICC Withdrawal" The East African, 6 December 2016, http://www.theeastafrican.co.ke/news/The-Gambia-new-pre sident-to-reverse-ICC-withdrawal/2558-3476690-pufyxjz/index.html. See also L Mogeni, 'Gambia May Not Join Other African States in ICC Withdrawal' The Wire, 9 December 2016, http://thewire.in/85747/gambia-icc-africa/; P Saine and L Jahateh, 'Gambia An nounces Plans to Stay in International Criminal Court', Reuters, 13 February 2017, http:// uk.reuters.com/article/uk-gambia-justice-icc-idUKKBN15S2HD. 
notification of withdrawal 'with immediate effect'. ${ }^{45}$ It also confirmed that 'The Gambia still considers itself as a state party and will continue to honour its obligations under the Rome Statute'. ${ }^{46}$ The rescission of The Gambia's notification of withdrawal was historic the first time a state has taken such a step. It offered some hope that the new Gambian government might help pave the way to accountability in the future. The rescission of the withdrawal notification means that it is still possible for the ICC to investigate the situation in The Gambia.

\subsection{Alleged Loss of Credibility by the ICC}

The South African government claimed that the ICC as a judicial body has lost its credibility primarily because of the Court's relationship with the UN Security Council as a UN political organ. South Africa further stated that the ICC has lost credibility due to 'the perceived focus of the ICC on African states, notwithstanding clear evidence of violations by others [commission of international crimes outside Africa]'. ${ }^{47}$ This view was restated by The Gambia's information minister, Sheriff Baba Bojang, who claimed that The Gambia's withdrawal notification was 'warranted by the fact that the ICC, despite being called International Criminal Court, is in fact an International Caucasian Court for the persecution and humiliation of people of colour, especially Africans'. ${ }^{48}$ Has the ICC lost its credibility due to its relationship with the UN Security Council to justify withdrawal by (some African) state parties? Has it been selective on investigating and prosecuting crimes committed only by Africans in African states while ignoring similar or worse crimes committed outside Africa?

\subsubsection{The UN Security Council Exclusive Referral of Situations in Africa to the ICC}

The UN Security Council, a political body, acting on behalf of all UN member states to maintain international peace and security

\footnotetext{
${ }^{45}$ UN, Gambia: Withdrawal of Notification of Withdrawal, C.N.62.2017. TREATIES-XVIII.10 (16 February 2017).

${ }^{46} \mathrm{Ibid}$.

${ }^{47}$ Declaratory Statement (n 27). Both the US and Russia signed but never ratified the Rome Statute and later 'unsigned' the Statute.

48 J Bavier 'Gambia Announces Withdrawal from International Criminal Court' 26 October 2016, http://uk.reuters.com/article/uk-gambia-icc-idUKKCN12P333.
} 
under Chapter VII of the UN Charter, ${ }^{49}$ has power to give the ICC jurisdiction by referring a 'situation' to the ICC Prosecutor in which one or more crimes within the ICC jurisdiction appear to have been committed. ${ }^{50}$ The Security Council can trigger proceedings over the crime of aggression. ${ }^{51}$ The referral practice of the Council has been characterised by double standards, lack of consistence and coherence as well as inaction or lack of effective support after referral. The ICC as an independent permanent international organisation is entirely autonomous from, but has an important relationship with, the UN. ${ }^{52}$ Since the ICC does not participate in the Security Council's decisionmaking, it is not responsible for the Council's practice.

However, its credibility as a judicial body has certainly been affected by the Council's practice. The Council has to date referred two situations to the Prosecutor, exclusively in Africa - Darfur (Sudan) ${ }^{53}$ and Libya, ${ }^{54}$ which does not reflect the aspiration to the universal vocation of the Court. In both situations, the Council required that Sudan and Libya 'cooperate fully' and 'provide any necessary assistance to the Court'. ${ }^{55}$ Nevertheless, notwithstanding Article 115 of the Rome Statute, ${ }^{56}$ the Council did not provide financial support for expenses associated with the investigations and prosecutions. ${ }^{57}$

${ }^{49}$ Charter of the United Nations, adopted 26 June 1945, entered into force 24 October 1945,1 UNTS XVI, Arts 24(1), 39, 41, 48 and 103.

${ }^{50}$ Rome Statute (n1), Art 13(b).

${ }^{51}$ Ibid., Art 15ter.

${ }^{52}$ Ibid., Art 2; Negotiated Relationship Agreement between the International Criminal Court and the United Nations, ICC-ASP/3/Res.1, 4 October 2004.

53 SC Resolution 1593, UN Doc S/RES/1593 (31 March 2005).

${ }^{54}$ SC Resolution 1970, UN Doc. S/RES/1970 (26 February 2011). Although the situation in Libya may be seen as concerning mainly 'Arabs', Libya is geographically located in Africa and a member of the African Union. Cases arising out of the Libyan referral (Saif Al-Islam Gaddafi and Abdullah Al-Senussi) deal with Africans.

${ }^{55}$ SC Resolution 1593 (n 53) para 2; SC Resolution 1970 (n 54), para 5.

${ }^{56}$ Rome Statute (n 1), Art 115 provides that in addition to assessed contributions made by States Parties, the expenses of the Court shall be provided by the: 'Funds provided by the United Nations, subject to the approval of the General Assembly, in particular in relation to the expenses incurred due to referrals by the Security Council'.

${ }^{57}$ SC Resolution 1593 (n 53), para 7; SC Resolution 1970 (n 54), para 8; Twelfth Report of the Prosecutor of the International Criminal Court to the United Nations Security Council pursuant to UNSCR 1970 (2011), 9 November 2016, para 30 noting: 'the Council has so far failed to provide any meaningful support, financial or otherwise, to the Office [of the Prosecutor's] work in Libya'. 
Similarly, it did not provide political support to the ICC or take any other follow-up actions to ensure that ICC arrest warrants are executed by both state parties and non-state parties, ${ }^{58}$ leaving the Prosecutor unable to prosecute cases from $\operatorname{Sudan}^{59}$ and to obtain custody of Saif Al-Islam Gaddafi from Libya. ${ }^{60}$ In fact, five suspects who are members of the Government of the Republic of Sudan or its aligned militias remain at large in Sudan, many years after arrest warrants were issued against them. ${ }^{61}$ Two warrants for the arrest of Omar Al-Bashir subsequently issued by Pre-Trial Chamber I (the first on 4 March 2009 for a number of war crimes and crimes against humanity ${ }^{62}$ and the second on 12 July 2010 for the crime of genocide) ${ }^{63}$ have not been executed. Instead $\mathrm{Al}$ Bashir has been able to travel across several international borders without arrest and surrender to the Court, thereby openly undermining Resolution 1593 and the credibility of the Council as well as the Court.

It is well known that Africa is seriously underrepresented on the UN Security Council, which is steered primarily by great powers who are permanent members namely China, France, Russia, the United Kingdom (UK) and the United States (US). According the South African government: 'Questions on the credibility of the ICC will persist so long as three of the five permanent members of the Security

${ }^{58}$ The Prosecutor v. Omar Hassan Ahmad Al Bashir, Decision Regarding the Visit of Omar Hassan Ahmad Al Bashir to the Federal Republic of Ethiopia, ICC-02/0501/09, 29 April 2014, para 12 Pre-Trial Chamber II observed that the Security Council by means of a resolution adopted under Chapter VII of the UN Charter, may "create an obligation to cooperate with the Court on those UN Member States which are not parties to the Statute. In such a case, the obligation to cooperate stems directly from the UN Charter'.

${ }^{59}$ See Twenty-Fourth Report of The Prosecutor of the International Criminal Court to the United Nations Security Council Pursuant to UNSCR 1593 (2005), 13 December 2016, para 36 observing: 'the Council, as an important pillar of enforcement, has not taken the follow-up steps necessary to ensure that accountability is realised in practice'. See also Ms. Bensouda in UN Security Council, Reports of the Secretary-General on the Sudan and South Sudan, UN Doc S/PV.7337 (12 December 2014), 2.

${ }^{60}$ Twelfth Report of the Prosecutor (n 57), paras 3-9.

${ }^{61}$ These suspects are Messrs Omar Hassan Ahmad Al Bashir, Ahmad Muhammad Harun, Ali Muhammad Ali Abd-Al-Rahman, Abdel Raheem Muhammad Hussein, and Abdallah Banda Abakaer Nourain.

${ }^{62}$ Pre-Trial Chamber I, 'Warrant of Arrest for Omar Hassan Ahmad Al Bashir', ICC-02/05-01/09-1.

${ }^{63}$ Pre-Trial Chamber I, 'Second Warrant of Arrest for Omar Hassan Ahmad Al Bashir', ICC- 02/05-01/09-95. 
Council [China, Russia and the US] are not State Parties to the Statute. ${ }^{64}$ This is primarily due to their status as non-state parties and veto power. South Africa's view suggests that the Security Council, which is still stuck in the post Second World War hegemony, has referred African situations to the ICC but ignored similar or worse situations elsewhere e.g. Afghanistan, Iraq, North Korea, Palestine, Sri Lanka, Syrian Arab Republic (Syria), Ukraine, and the US with respect to methods used in interrogations and detention since $9 / 11$.

Situations involving interests of some major political and economic states which are permanent members of the UN Security Council or their allies would never be referred to the ICC. For example, the situation in Afghanistan did not attract a UN Security Council referral despite the existence of 'a reasonable basis to believe' that crimes were committed in 2003-2004 (continuing in some cases until 2014) within the Court's jurisdiction, in particular 'war crimes of torture and related ill-treatment, by US military forces deployed to Afghanistan and in secrete detention facilities operated by the Central Intelligence Agency'. ${ }^{65}$ The US would use its veto power against such a referral investigating crimes committed by US military officials.

In May 2014, Russia and China vetoed a draft UN Security Council resolution calling for the referral of the situation in Syria since 15 February 2011 to the ICC Prosecutor-ignoring support for the referral by 65 other states and all other 13 members of the Security Council including African states non-permanent members (Chad and Rwanda). ${ }^{66}$ This was intended to shield the regime of President Bashar al-Assad, to which Russia had tied itself over decades, from ICC investigations and potential prosecutions. Thus while the Security Council can theoretically refer any situation to the ICC, in practice only a certain group of states can be referred to the ICC

\footnotetext{
${ }^{64}$ See Declaratory Statement (n 27).

${ }^{65}$ ICC, The Office of the Prosecutor, Report on Preliminary Examination Activities 2016, 14 November 2016, https://www.icc-cpi.int/iccdocs/otp/161114-otp-rep-PE_ ENG.pdf, para 198(c).

${ }^{66}$ UN Security Council, Draft Resolution (proposed by France), UN Doc. S/ 2014/348 (22 May 2014); UN Security Council, Referral of Syria to International Criminal Court Fails as Negative Votes Prevent Security Council from Adopting Draft Resolution, SC/11407 (22 May 2014), http://www.un.org/press/en/2014/ sc11407.doc.htm.
} 
due to 'prevailing geo-strategic and international political reasons' among the permanent UN Security Council members. ${ }^{67}$

Consequently, this has created a perception that it is only African sitting heads of state (starting with Al Bashir of Sudan in 2009, Gaddafi of Libya in 2011, Kenyatta and Ruto of Kenya in 2012) that commit international crimes and need intervention from the ICC. This has provided a basis for some African leaders to criticise or perceive the ICC as 'a biased instrument of post-colonial hegemony ${ }^{68}$ which is intended for developing and weak countries and was a tool to exercise cultural superiority ${ }^{69}$ and thus a 'vessel for oppressing Africa again' ${ }^{70}$ While there is some merit in criticising the practice of the Security Council, two observations should be noted.

First, it must be acknowledged that none of the African nonpermanent Security Council members voted against the UN Security Council referrals in Darfur and Libya: Gabon, Nigeria and South Africa voted in favour of the Libyan referral, ${ }^{71}$ while Benin and Tanzania voted in favour of the Darfur referral. ${ }^{72}$ Thus African states

${ }^{67}$ International Criminal Tribunal for Rwanda (ICTR), The Prosecutor v Joseph Kanyabashi, Decision on the Defence Motion on Jurisdiction, ICTR-96-15-7, 18 June 1997, para 36 noting: 'The fact that the Security Council, for previously prevailing geo-strategic and international political reasons, was unable in the past to take adequate measures to bring to justice the perpetrators of crimes against international humanitarian law is not an acceptable argument against introducing measures to punish serious violations of international humanitarian law when this becomes an option under international law.'

${ }^{68}$ F Makana, 'Ugandan President Yoweri Museveni Lashes out at ICC, Wants Africa to Pull Out' Standard, 13 December 2014, http://www.standardmedia.co.ke/ article/2000144601/ugandan-president-yoweri-museveni-lashes-out-at-icc-wants-afri ca-to-pull-out.

${ }^{69}$ See Security Council, 'Security Council Refers Situation in Darfur, Sudan, to Prosecutor of International Criminal Court', 5158th Meeting, SC/8351(31 March 2005), statement by the representative of the Sudan, Elfatih Mohamed Ahmed Erwa, http://www.un.org/press/en/2005/sc8351.doc.htm.

${ }^{70}$ D Miriri, 'Uganda's Museveni Calls on African nations to quit the ICC' Reuters, 12 December 2014, http://www.reuters.com/article/us-africa-icc-idUSKBN0JQ1 DO20141212. President Museveni described the ICC as a 'vessel for oppressing Africa again'.

${ }^{71}$ See Security Council, 6491st Meeting, SC/10187/REV.1, 26 February 2011, http://www.un.org/press/en/2011/sc10187.doc.htm. SC Resolution 1970, was adop ted unanimously. South African representative, Baso Sangqu, stated that 'the mea sures it [SC Resolution 1970] contained could contribute to the long-term objective of bringing peace and stability to the nation'.

${ }^{72}$ See Security Council, 5158th Meeting, SC/8351, 31 March 2005, http://www.un. org/press/en/2005/sc8351.doc.htm. SC Resolution 1593 (2005) was adopted by a vote 
non-permanent Security Council members including South Africa have contributed to the practice of Security Council referrals of African situations to the ICC. The five permanent members would be unable to refer a situation without the concurrent vote of other nonpermanent members, since a Chapter VII decision requires a majority. Besides, there is no doubt that attacks on the civilian population in Darfur were war crimes and crimes against humanity. ${ }^{73}$ It is in this context that the AU Commission of Inquiry on South Sudan recommended that 'those with the greatest responsibility for the atrocities at the highest level should be brought to account' ${ }^{74}$ Since Sudan was unable or unwilling to do so, the Security Council referral of the situation in Darfur to the ICC is understandable.

Second, any investigation and proceedings that may arise from any situation referred by the UN Security Council to the ICC is not determined by the Security Council but governed by the Rome Statute and the ICC Rules of Procedure and Evidence. ${ }^{75}$ Decisions are made by the ICC independent judges through a judicial process and are "not influenced by the Security Council or any other external body'. ${ }^{76}$ No evidence exists to show any lack of independence on the part of ICC judges in the performance of their judicial functions. ${ }^{77}$

Nonetheless, the current practice of the UN Security Council referral of African situations while ignoring non-African situations reflects wider political dynamics at the Security Council. Pressure by some UN Security Council permanent members undermines efforts at accountability and impedes the Council from carrying out its referral

Footnote 72 continued

of 11 in favour, none against with 4 abstentions (Algeria, Brazil, China, United States).

${ }^{73}$ See Report of the International Commission of Inquiry on Darfur to the United Nations Secretary-General, Pursuant to Security Council Resolution 1564 of 18 September 2004, 25 November 2005, http://www.un.org/news/dh/sudan/com_inq_ darfur.pdf.

${ }^{74}$ Final Report of the African Union Commission of Inquiry on South Sudan, 15 October 2014, http://www.peaceau.org/uploads/auciss.final.report.pdf, para 1142.

${ }^{75}$ See Rome Statute (n 1); ICC Rules of Procedure and Evidence, ICC-ASP/1/3 and Corr.1, part II.A, https://www.icc-cpi.int/iccdocs/PIDS/legal-texts/Rule sProcedureEvidenceEng.pdf.

${ }^{76}$ See Statement by the ICC Presidency, 'ICC Underlines Impartiality, Reiterates Commitment to Cooperation with the African Union', ICC-CPI-20130529-PR908, 29 May 2013, https://www.icc-cpi.int/Pages/item.aspx?name $=$ pr908\&ln $=$ en.

${ }^{77}$ Independence of ICC judges is secured through Articles 40, 36, 46, 47 and 49 of the Rome Statute. 
duties to the ICC Prosecutor in an impartial and effective manner. It also undermines attempts to adopt resolutions that would have helped to hold parties accountable. For instance, in the past five years, Russia has vetoed seven Security Council texts on the Syrian conflict, while China has cast a negative vote six times on the issue. ${ }^{78}$ The UN Security Council remains a political body that is subject to veto wielding and has been inconsistent in referring situations to the ICC. In this context, the UN Secretary General noted:

[T] here remain serious challenges in pursuing accountability. Some situations which, by any objective analysis, would have warranted some form of action by the Security Council, have faced serious obstacles or languished entirely. This has eroded the Council's credibility. There is a need to address this problem, and to bring some consistency to the effort. ${ }^{79}$

It is essential for the Council to correct its failings by taking concrete action to refer all deserving situations to the ICC. This requires developing a transparent and consistent policy setting out objective criteria for deciding whether or not to refer a situation to the ICC without any perception of double standards. This will provide an opportunity for the ICC to extend its global reach.

\subsubsection{Security Council Exemption of the US Nationals from the ICC Jurisdiction}

In 2002 the US passed the American Service-members Protection Act, which prohibits cooperation with the ICC. $^{80}$ Based on the insistence of the US, the two Security Council referrals in Darfur and Libya limited the personal scope of ICC jurisdiction by excluding certain categories of individuals from non-state parties to the Rome Statute. In the Darfur referral, for example, the Council decided that:

nationals, current or former officials or personnel from a contributing State outside Sudan which is not a party to the Rome Statute of the International

\footnotetext{
${ }^{78}$ See UN News Centre, Russia, China block Security Council Action on Use of Chemical Weapons in Syria, 28 February 2017, http://www.un.org/apps/news/story. asp?NewsID $=56260 \#$. WLcmJvmLTIU.

${ }^{79}$ Secretary-General, Honouring Geneva Conventions, Secretary-General Says Debate 'No Longer between Peace and Justice but between Peace and What Kind of Justice', SG/SM/12494, L/T/4417, HR/5002 (26 September 2009), http://www.un. org/press/en/2009/sgsm12494.doc.htm.

${ }^{80}$ American Service-members' Protection Act of 2002, https://legcounsel.house. gov/Comps/aspa02.pdf, sec 2004.
} 
Criminal Court shall be subject to the exclusive jurisdiction of that contributing State for all alleged acts or omissions arising out of or related to operations in Sudan established or authorized by the Council or the African Union, unless such exclusive jurisdiction has been expressly waived by that contributing State. ${ }^{81}$

The above paragraph, which discriminates on the basis of nationality, was intended to protect US nationals from the ICC jurisdiction and it was included in the SC resolution as a condition for the US not to veto the resolution. ${ }^{82} \mathrm{~A}$ similar paragraph was included in the SC resolution referring the Situation in Libya to the ICC Prosecutor, ${ }^{83}$ and in the draft resolution for the Syria referral. ${ }^{84}$ Such discriminatory referrals were criticised by states upon adoption. ${ }^{85}$ The Office of the Prosecutor (OTP) stated that it has not accepted the effects of the above discriminatory paragraph and it has stated before the UN Security Council that it has competence over NATO troops in Libya. Nonetheless, these referrals were acted upon by the Court without determining whether the UN Security Council resolutions of situations in Darfur and Libya were compatible with article 13(b) of the Rome Statute and the principle of non-discrimination. The Security Council is not empowered to impose discriminatory exemptions to the exercise of the jurisdiction of the ICC. It follows that discriminatory exemptions granting immunity to nationals of non-state parties who commit crimes in a situation referred to the Court do not bind the ICC. Nonetheless by acting upon the UN Security Council referrals in Sudan and Libya, without any judicial determination of the effect of the purported exemption clauses on the exercise of the Court's jurisdiction, the ICC appears to have, at least in practice,

${ }^{81}$ SC Resolution 1593, UN Doc S/RES/1593 (31 March 2005), para 6.

${ }^{82}$ UN SC, 5158th Meeting 31 March 2005, United States, UN Doc. S/PV.5158, at 4, http://www.un.org/en/ga/search/view_doc.asp?symbol=S/PV.5158: US ambas sador, Mrs. Patterson, explained that: 'This resolution provides clear protections for United States persons. No United States person supporting the operations in the Sudan will be subject to investigation or prosecution because of this resolution.'

${ }^{83}$ SC Resolution 1970, UN Doc. S/RES/1970 (26 February 2011), para 6.

${ }^{84}$ UN Doc. S/2014/348 (22 May 2014) para 7. Argentina objected to this paragraph. See The Situation in the Middle East (Syria), UN Doc S/PV.7180, 22 May 2014, record of debates on draft resolution $\mathrm{S} / 201 / 348$, at 11.

${ }^{85}$ See eg statements made by representatives of Argentina, Brazil and Philippines, Records of Debates on Draft Resolution S/2005/218, UN Doc S/PV.518 (31 March 2005), at 6-8, 11; Brazil, 'Peace and Security in Africa', UN Doc S/PV.6491 (26 February 2011), Record of Debates on Draft Resolution S/2011/95, at 7. 
implicitly accepted the exemption paragraphs. ${ }^{86}$ Although the OTP stated that it has not accepted the effects.

A 'situation' under article 13(b) must be referred to the Prosecutor without any prohibited discriminatory limitation. Under Article 21(3) of the Rome Statute the application and interpretation of law by the Court 'must be consistent with internationally recognized human rights, and be without any adverse distinction founded on grounds such as gender, ... age, race, colour, language, religion or belief, political or other opinion, national, ethnic or social origin, wealth, birth or other status' ${ }^{87}$ This applies to 'all of its [the Court's] constituent organs' ${ }^{88}$ namely the Presidency, the Chambers, the Office of the Prosecutor and the Registry. ${ }^{89}$ Only then can the Prosecutor, in exercising prosecutorial discretion in selecting situations and cases under the Rome Statute, ${ }^{90}$ and the Court, observe the 'interests of justice' including the principle of equality before the law and nondiscrimination, which flows from principles of independence, impartiality and objectivity. ${ }^{91}$

Discriminatory Security Council referrals leading to investigations and prosecutions which exclude individuals (who may have committed crimes within the ICC's jurisdiction) on the basis of nationality have indeed undermined the credibility of the ICC by subsuming

\footnotetext{
${ }^{86}$ But see contra R Rastan, 'Jurisdiction', in C Stahn (ed), The Law and Practice of the International Criminal Court (Oxford University Press, 2015) 141-178, at 158163.
}

${ }^{87}$ Rome Statute, Art 21(3). See also ICTY Judgment, Prosecutor v Delalić et al. (Čelebići case), IT-96-21-A, Appeals Chamber, 20 February 2001, paras 605, 611, http://www.icty.org/x/cases/mucic/acjug/en/cel-aj010220.pdf.

${ }^{88}$ The Prosecutor v Germain Katanga and Mathieu Ngudjolo Chui, Decision on an Amicus Curiae application and on the "Requête tendant à obtenir présentations des témoins DRC-D02-P-0350, DRC-D02-P-0236, DRC-D02-P-0228 aux autorités néerlandaises aux fins d'asile" (articles 68 and 93(7) of the Statute), ICC-01/04-01/07 (9 June 2011), para 77.

${ }^{89}$ Rome Statute (n 1), Art 34.

${ }^{90}$ Ibid., Art 53(1)(a)-(c). In determining whether there is a 'reasonable basis' to proceed with an investigation into a situation the Prosecutor considers: (i) jurisdiction (temporal, either territorial or personal, and material); (ii) admissibility (complementarity and gravity); and (iii) the interests of justice.

${ }^{91}$ See Rome Statute (n 1), Arts 21(3), 42(1 and 7) and 54(1)(a); OTP, Policy Paper on Case Selection and Prioritisation, 15 September 2016, https://www.icc-cpi.int/ itemsDocuments/20160915_OTP-Policy_Case-Selection_Eng.pdf, para 16: 'The Of fice shall conduct its case selection and prioritisation on the basis of the overarching principles of independence, impartiality and objectivity'. 
'the independence of the ICC into the political and diplomatic vagaries of the Security Council'. ${ }^{92}$ As noted above, this is particularly the case given that three permanent members of the UN Security Council namely Russia, China, and the US are not parties to the Rome Statute and thus are outside the ICC's jurisdiction. It should be recalled that when the Rome Statute was adopted in 1998, 120 states voted for the establishment of the ICC with 21 abstentions and 7 against (including the US, Israel and China). ${ }^{93}$

Both the US ${ }^{94}$ and Russia ${ }^{95}$ signed the Rome Statute in 2000 but later 'unsigned' the Statute by making their 'intention clear not to become a party to the treaty', in 2002 and 2016 respectively. ${ }^{96}$ Russia's withdrawal was made shortly after the ICC Prosecutor examined crimes allegedly committed in the context of Russia's military actions in Georgia, Crimea and Ukraine and called the Crimea situation an international armed conflict and occupation. ${ }^{97}$ Both the US and Russia intended to cancel their legal obligation to refrain from defeating the object and purpose of the Rome Statute i.e. not to create conditions for or facilitate in any way the commission of genocide, crimes against humanity, war crimes and aggression. ${ }^{98}$

${ }^{92}$ UN SC, 5158th Meeting 31 March 2005, Philippines, UN Doc. S/PV.5158, 6, http://www.un.org/en/ga/search/view_doc.asp?symbol=S/PV.5158.

${ }^{93}$ See United Nations Diplomatic Conference of Plenipotentiaries on the Establishment of an International Criminal Court Rome, Italy 15 June - 17 July 1998, UN Doc A/CONF.183/SR.9, 9th Plenary Meeting, paras 28, 33 and 40; M Cherif Bassiouni and WA Schabas (eds), The Legislative History of the International Criminal Court, 2nd edn (Brill/Nijhoff, 2016) 101.

${ }^{94}$ The US signed the Rome Statute on 31 December 2000 but 'unsigned' the Statute on 6 May 2002 by making clear to the UN Secretary-General its intention 'not to become a party'.

${ }^{95}$ See Bylaw No 361-rp, 'On the Russian Federation's intention not to become a party to the Rome Statute of the International Criminal Court' (16 November 2016), http://publication.pravo.gov.ru/Document/View/0001201611160018. Russia signed the Rome Statute on 13 September 2000 but 'unsigned' it on 30 November 2016 by informing the UN Secretary-General of Russia's intention 'not to become a party to the Rome Statute'.

${ }^{96}$ Rome Statute of the International Criminal Court, 17 July 1998, https://treaties. un.org/doc/Publication/MTDSG/Volume\%20II/Chapter\%20XVIII/XVIII-10.en. pdf.

${ }^{97}$ See The Office of the Prosecutor, Report on Preliminary Activities 2016 (14 November 2016) 33-42.

98 Vienna Convention on the Law of Treaties, concluded at Vienna on 23 May 1969, entered into force 27 January 1980 (1980) 1155 UNTS 331, Art 18(a). 
Accordingly, they made it clear that they do not intend to ratify the Statute in the future or of cooperating with the ICC in a meaningful way. This was part of the strategy to shield American and Russian nationals from potential ICC prosecutions in the future.

Thus while powerful permanent UN Security Council members non-parties to the Rome Statute are highly influential in deciding which 'situation' should be referred to the ICC Prosecutor to determine whether a particular situation should give rise to a criminal investigation, they have been able to avoid ICC investigations and prosecutions. De facto, they enjoy immunity from ICC investigations and prosecutions arising from the prospect of a UN Security Council referral. They have used their veto privilege to block referral of situations involving their allies to the ICC Prosecutor. This has been the case in states that are not parties to the Rome Statute - and have not accepted the jurisdiction of the Court on an ad hoc basis- but allies of some UN Security Council permanent members. For example, despite existence of evidence showing that crimes within the jurisdiction of the ICC appear to have been committed in Syria a referral to the ICC was blocked. ${ }^{99}$ In the words of the Russian Federation delegate:

The United States frequently indicates the ICC option for others, but is reluctant to accede to the Rome Statute itself. In today's draft resolution, ${ }^{100}$ the United States insisted on an exemption for itself and its citizens. Great Britain is a party to the ICC, but for some reason is unenthusiastic about the exploration in the Court of crimes committed by British nationals during the Iraq war. If the United States and the United Kingdom were to together refer the Iraqi dossier to the ICC, the world would see that they are truly against impunity. ${ }^{101}$

The criticism above reveals that Russia is well aware that some states in particular the US support ICC investigations for crimes committed

${ }^{99}$ See reports of the Independent International Commission of Inquiry on the Syrian Arab Republic,http://www.ohchr.org/EN/HRBodies/HRC/IICISyria/Pages/ IndependentInternationalCommission.aspx; UN Security Council, Draft Resolution (proposed by France), UN Doc. S/2014/348 (22 May 2014); UN Security Council, Referral of Syria to International Criminal Court Fails as Negative Votes Prevent Security Council from Adopting Draft Resolution, SC/11407 (22 May 2014), http:// www.un.org/press/en/2014/sc11407.doc.htm.

${ }^{100}$ UN Security Council, Draft Resolution (proposed by France), UN Doc. S/ 2014/348 (22 May 2014).

${ }^{101}$ UN Security Council, 7180th Meeting, 22 May 2014, S/PV.5158, Mr. Churkin (Russian Federation), 13 http://www.un.org/en/ga/search/view_doc.asp?symbol = S/ PV.7180. It should be noted that the UK cooperated with the IC C's Iraq preliminary inquiry, and has carried out investigations and some court martials. 
by others but not for their nationals or their allies. Therefore Russia also vetoed a proposed UN Security Council resolution to refer the situation in Syria to the ICC despite the existence of 'a reasonable basis to believe' that war crimes and crimes against humanity were committed in Syria ${ }^{102}$ including 'indiscriminate and disproportionate attacks on civilian-inhabited areas, particularly through pounding aerial bombardments', unlawful killings, enforced disappearance, hostage-taking, torture, and sexual violence. ${ }^{103}$ It should be noted that the Independent International Commission of Inquiry on the Syrian Arab Republic recommended that the Security Council takes appropriate action 'by referring the situation [in Syria] to justice, possibly to the International Criminal Court or an ad hoc tribunal, bearing in mind that, in the context of the Syrian Arab Republic, only the Security Council is competent to refer the situation'. ${ }^{104}$ However, no action was taken by the Security Council mainly because of Russian and Chinese resistance.

The UN General Assembly sidestepped the Security Council by deciding in Resolution 71/248 to establish the International, Impartial and Independent Mechanism to Assist in the Investigation and Prosecution of Those Responsible for the Most Serious Crimes under International Law Committed in the Syrian Arab Republic since March 2011' (the IIIM or the Mechanism). ${ }^{105}$ This is a significant historic step since it marked the first time the Assembly has established such a Mechanism. The Mechanism is a fact-finding body that will rely solely on the voluntary cooperation of states, NGOs and individuals to 'collect, consolidate, preserve and analyse' evidence of crimes for future prosecutions. ${ }^{106}$ It will not prosecute anyone but

${ }^{102}$ See eg Resolution adopted by the Human Rights Council on 21 October 2016:The Deteriorating Situation of Human Rights in the Syrian Arab Republic, and the Recent Situation in Aleppo, UN Doc A/HRC/RES/S-25/1 (25 October 2016). The Resolution strongly condemned 'all attacks against civilians and civilian infrastructure'.

${ }^{103}$ See Report of the Independent International Commission of Inquiry on the Syrian Arab Republic, A/HRC/33/55 (11 August 2016).

${ }^{104}$ Ibid., para 147 (c).

105 See UN General Assembly, International, Impartial and Independent Mechanism to Assist in the Investigation and Prosecution of Those Responsible for the Most Serious Crimes under International Law Committed in the Syrian Arab Republic since March 2011, A/71/L.48, 19 December 2016, http:/www.un.org/ga/ search/view_doc.asp?symbol=A/71/L.48, para 4 . The vote was 105 to 15 , with 52 abstentions. The US voted in favour of the measure.

106 Ibid., para 4. 
'prepare files in order to facilitate and expedite fair and independent criminal proceedings' in national, regional or international courts or tribunals that have or may in the future have jurisdiction over these crimes, in accordance with international law. ${ }^{107}$

Unlike the Security Council, the General Assembly lacks the authority to refer the situation in Syria to the ICC or to establish an ad hoc international criminal tribunal for Syria with the legal authority to charge individual perpetrators or to require state cooperation. Furthermore, it cannot mandate states to cooperate with the ICC, though it can recommend that the Security Council take such actions in the future to ensure that perpetrators of international crimes in Syria are held accountable. ${ }^{108}$ It is worth noting that the General Assembly has been involved in prior accountability efforts since 1946 to promote cooperation by states to investigate and punish international crimes. ${ }^{109}$ Thus, establishing such a Mechanism builds upon earlier practice of the General Assembly with respect to investigative bodies such as Commissions of Inquiry or Expert Panels with a view to assisting future accountability efforts. However, Russia (and Syria) have opposed this Mechanism on the basis that it was granted powers 'prosecutorial in nature', which the General Assembly does not itself possess. Thus, Russia claimed that 'the General Assembly acted ultra vires - going beyond its powers' as set out in the UN Charter. ${ }^{110}$ This is incorrect because the powers of the Mechanism do not include the prosecution of anyone and cannot, therefore,

\footnotetext{
107 Ibid.

108 The General Assembly has limited powers under the UN Charter Arts 10, 11, 13, and 22. See B Simma, et al., The Charter of the United Nations: A Commentary, 2nd edn. (Oxford University Press, 2002) 427-428; LM Goodrich, et al., Charter of the United Nations, 3rd edn (Columbia University Press, 1969) 191; A Whiting, 'An Investigation Mechanism for Syria: The General Assembly Steps into the Breach' (2017) 15(2) Journal of International Criminal Justice, https://doi.org/10.1093/jicj/ mqx008; C Wenaweser and J Cockayne, 'Justice for Syria?: The International, Impartial and Independent Mechanism and the Emergence of the UN General Assembly in the Realm of International Criminal Justice'(2017) 15(2) Journal of International Criminal Justice,https://doi.org/10.1093/jicj/mqx010.

${ }^{109}$ See eg the following GA resolutions: Resolution 3 (13 February 1946); Resolution 95 (11 December 1946); Resolution 3074 (3 December 1973); Resolution 52/ 135 (12 December 1997); Resolution 57/228(B) (22 May 2003); Resolution 60/147 (16 December 2005); Resolution 63/19 (16 December 2008).

${ }^{110}$ Note Verbale dated 8 February 2017 from the Permanent Mission of the Russian Federation to the United Nations addressed to the Secretary General, UN Doc A/71/793, 14 February 2017; General Assembly, 66th Plenary Meeting, 21 December 2017, Official Records, A/71/PV.66, at 21-23.
} 
be considered as being 'prosecutorial in nature'. Accordingly, the opposition to the Mechanism is political rather than strictly legal. The Mechanism is an important step in the promotion of the principle of accountability for international crimes. This is because it provides a way to 'collect, consolidate, preserve and analyse' evidence of crimes to criminal law standards (identifying perpetrators for possible future prosecution) where there exists political resistance preventing any international tribunal from investigating and prosecuting crimes committed in Syria. ${ }^{111}$ This increases the prospects of future accountability and justice for Syria since the Mechanism is aimed at assisting any recognised exercise of criminal jurisdiction, whether by Syria, any other state, or competent international or regional court/ tribunal. It also presents an important precedent for future situations faced with a political impasse within the Security Council.

\subsubsection{Has the ICC Unfairly Focused on Africa?}

Credibility of a judicial institution, like the ICC, depends in part on its independence and its performance. While it is true that the ICC's first active investigations and prosecutions were exclusively in Afri$\mathrm{ca},{ }^{112}$ three observations must be noted. First, five African situations - Central African Republic (CAR), Côte d'Ivoire, Democratic Republic of the Congo (DRC), Mali, and Uganda - were 'self-referrals' brought voluntarily to the ICC by concerned African states so that the Court can investigate and prosecute domestic leaders/commanders of rebel groups in Africa. Both the Union of the Comoros (Comoros) and Gabon have also referred situations on their territories to the ICC. While a state party to the Rome Statute may refer to the ICC Prosecutor for investigation 'a situation in which one or more crimes within the jurisdiction of the Court appear to have been committed' (in any other ICC state party), ${ }^{113}$ with the exception of

${ }^{111}$ See Report of the Secretary General: Implementation of the Resolution Establishing the International, Impartial and Independent Mechanism to Assist in the Investigation and Prosecution of Persons Responsible for the Most Serious Crimes under International Law Committed in the Syrian Arab Republic since March 2011, A/71/755, 19 January 2017.

112 The Office of the ICC Prosecutor has carried out investigations in Uganda (since 2004), the Democratic Republic of the Congo (DRC, since 2004), Darfur in Sudan (since 2005), the Central African Republic (CAR, since 2007), Kenya (since 2010), Libya (since 2011), Côte d'Ivoire (since 2011), Mali (since 2013), and another situation in CAR (since 2014). See ICC, Situations under Investigation, https://www. icc-cpi.int/pages/situations.aspx.

${ }^{113}$ Rome Statute (n 1), Arts 13(b) and 14. 
the Comoros ${ }^{114}$ no African state has ever referred or attempted to refer any situation outside Africa to the ICC for investigation. States have only made so-called 'self-referrals' because they contemplated the territory of the referring state generally targeting armed rebel groups. The 'self-referral' of African situations to the ICC by African states cannot be blamed on the ICC. African ICC member states that have complained of Africa-bias could have taken appropriate measures to remedy this claim by referring other (non-African) situations to the Court.

Second, the ICC Prosecutor's exercise of proprio motu powers in Kenya was based on information provided by Kofi Annan, the Chairman of the African Union (AU) Panel of Eminent African Personalities ${ }^{115}$ following the report of an Independent Commission of Inquiry (also known as Waki Commission, after its President, Justice Philip Waki). ${ }^{116}$ In any case, when the ICC found at the trial stage that the evidence against Kenyatta and Ruto was insufficient, charges were respectively withdrawn or vacated. ${ }^{117}$ Notably, the exercise of proprio motu powers in Cote d'Ivoire was upon voluntary acceptance of the Court's jurisdiction under Article 12(3) of the Rome Statute by the government. ${ }^{118}$ In both situations in Kenya and Cote d'Ivoire, the Pre-Trial Chambers of the Court independently

${ }^{114}$ The Comoros referral concerns an investigation of the situation on certain registered vessels (over crimes allegedly committed on board), registered respectively in the Comoros (the Mavi Marmara), Cambodia (the Rachel Corrie) and Greece (the Eleftheri Mesogios/Sofia). See ICC, Preliminary Examination: Registered Vessels of Comoros, Greece and Cambodia, https://www.icc-cpi.int/comoros.

115 ICC, 'ICC Prosecutor Receives Sealed Envelope from Kofi Annan on PostElection Violence in Kenya' (9 July 2009) Press Release No ICC-OTP-20090709PR436.

116 See Report of the Commission of Inquiry into Post-election Violence (2008) 18, 472-475; M Ssenyonjo, 'Analysing the Impact of the International Criminal Court Investigations and Prosecutions of Kenya's Serving Senior State Officials' (2014)1(1) State Practice \& International Law Journal 17.

${ }^{117}$ See The Prosecutor v Uhuru Muigai Kenyatta, Decision on the withdrawal of charges against Mr Kenyatta, ICC-01/09-02/11-1005, 13 March 2015; and The Prosecutor $v$ William Samoei Ruto and Joshua Arap Sang, Decision on Defence Applications for Judgments of Acquittal, ICC-01/09-01/11, 5 April 2016.

${ }^{118}$ See ICC, Situation in the Republic of Côte d'Ivoire, ICC-02/11, https://www.icccpi.int/cdi. Côte d'Ivoire was not a state party to the Rome Statute at the time but accepted the jurisdiction of the ICC on 18 April 2003; and on both 14 December 2010 and 3 May 2011, the Presidency of Côte d'Ivoire reconfirmed Côte d'Ivoire's acceptance of this jurisdiction. On 15 February 2013, Côte d'Ivoire ratified the Rome Statute. 
concurred with the Office of the Prosecutor and authorised the commencement of the investigations. ${ }^{119}$ In all African situations before the ICC, the ICC has acted to hold accountable perpetrators of the crimes for the benefit of African victims of alleged crimes that African states were unable or unwilling to investigate and prosecute. This contributes to lasting peace, security and stability in Africa. All ICC judicial decisions from the authorisation of investigations to the confirmation or non-confirmation of charges and decisions on guilt or innocence are and have been 'taken independently on the basis of the law and the available evidence and are not based on regional or ethnic considerations'. ${ }^{120}$

Third, the Prosecutor has since made good progress by investigating situations outside Africa as reflected in an investigation opened in Georgia in 2016. ${ }^{121}$ In addition, although in the past the Prosecutor decided not to proceed in certain politically complex nonAfrican situations, such as with Iraq, Korea, Palestine and Venezuela, on the basis that the legal criteria under Article 53 was not met, there has been a change in approach. At the time of writing, the Prosecutor's was carrying out preliminary examinations in nonAfrican situations including Afghanistan, Colombia, Iraq (UK military intervention in Iraq), Palestine, Registered vessels of Greece and Cambodia, and Ukraine. ${ }^{122}$ Such recent developments indicate that the Prosecutor is willing to investigate non-African situations. In this context the Prosecutor's announcement to reach a final determination with respect to the situation in Afghanistan and the Comoros referral is to be welcomed. ${ }^{123}$ It should be noted, however, that many preliminary examinations are mired in delays.

${ }^{119}$ See Rome Statute (n 1), Art 15; Pre-Trial Chamber II, Situation in the Republic of Kenya: Decision Pursuant to Article 15 of the Rome Statute on the Authorization of an Investigation into the Situation in the Republic of Kenya, ICC01/09, 31 March 2010; Pre-Trial Chamber III, Situation in the Republic of Cote D'ivoire: Decision Pursuant to Article 15 of the Rome Statute on the Authorisation of an Investigation into the Situation in the Republic of Côte d'Ivoire, ICC-02/11, 3 October 2011.

${ }^{120}$ See Statement by the ICC Presidency (n 76).

${ }^{121}$ Pre-Trial Chamber 1, Situation in Georgia: Decision on the Prosecutor's Request for Authorization of an Investigation, No. ICC-01/15, 27 January 2016.

122 ICC, The Office of the Prosecutor, Report on Preliminary Examination Activities 2016, 14 November 2016, https://www.icc-cpi.int/iccdocs/otp/161114-otp-repPE_ENG.pdf.

123 Ibid. 


\subsubsection{The ICC's Performance and Budget in the Last 14 Years}

Another element advanced to demonstrate the ICC's lack of credibility is based on the assessment of the ICC's performance during the last 14 years. The Court delivered its first judgment after a decade in existence on 14 March 2012 convicting Congolese militia leader Thomas Lubanga Dyilo of the war crimes of enlisting and conscripting children under the age of 15 years and using them to participate actively in hostilities. ${ }^{124}$ Since the first ICC Prosecutor's mandate began in mid-2003 up to the end of 2016, the Prosecutor had only been able to prosecute African non-state actors leading to 9 convictions by the Court in the following cases (Lubanga, ${ }^{125}$ Katanga, ${ }^{126}$ Bemba et al. ${ }^{127}$ and $\mathrm{Al} \mathrm{Mahdi}{ }^{128}$ ) and 1 acquittal ${ }^{129}$ at a

${ }^{124}$ The Prosecutor v Thomas Lubanga Dyilo, Judgment pursuant to Article 74 of the Statute, No. ICC-01/04-01/06, 14 March 2012. He was sentenced to a total of 14 years of imprisonment on 10 July 2012, and this was confirmed by Appeals Chamber on 1 December 2014.

${ }^{125}$ Ibid.

${ }^{126}$ The Prosecutor v Germain Katanga, Judgment pursuant to Article 74 of the Statute, ICC-01/04-01/07, 7 March 2014. He was found guilty, on 7 March 2014, as an accessory to one count of a crime against humanity (murder) and four counts of war crimes (murder, attacking a civilian population, destruction of property and pillaging) committed on 24 February 2003 during the attack on the village of Bogoro, in the Ituri district of the DRC. He was sentenced to a total of 12 years' imprisonment.

127 The Prosecutor v Jean-Pierre Bemba Gombo, Aimé Kilolo Musamba, JeanJacques Mangenda Kabongo, Fidèle Babala Wandu and Narcisse Arido, ICC-01/0501/13; The Prosecutor v Jean-Pierre Bemba Gombo, Judgment pursuant to Article 74 of the Statute, ICC-01/05-01/08, 21 March 2016. Trial Chamber III found Mr JeanPierre Bemba Gombo guilty under Article 28(a) of the Rome Statute, as a person effectively acting as a military commander, of the crimes of crimes against humanity (murder and rape) and war crimes (murder, rape and pillaging). He was sentenced to 18 years of imprisonment on 21 June 2016.

128 The Prosecutor v Ahmad Al Faqi Al Mahdi, Judgment and Sentence, ICC-01/ 12-01/15, 27 September 2016. Al Mahdi was found guilty of the crime of intentionally directing attacks against protected objects, alleged to have been committed between 30 June 2012 and 11 July 2012 in Timbuktu, Mali, against 10 sites of a religious and historic character. He was sentenced to 9 years.

129 The Prosecutor v Mathieu Ngudjolo Chui, Judgment on the Prosecutor's appeal against the decision of Trial Chamber II entitled "Judgment pursuant to article 74 of the Statute", ICC-01/04-02/12 A (7 April 2015). On 18 December 2012, Trial Chamber II acquitted Mathieu Ngudjolo Chui of the charges of war crimes and crimes against humanity and ordered his immediate release. The Prosecution appealed the verdict on 20 December 2012. On 27 February 2015, the verdict was upheld by the Appeals Chamber. 
cost of over one billion US dollars, making the ICC one of the most expensive courts in the world. ${ }^{130}$ At the time of writing, there were three ongoing cases at the trial stage involving former warlords from the $\mathrm{DRC}^{131}$ and Uganda, ${ }^{132}$ as well as the ex-President of Cote d'Ivoire. ${ }^{133}$

With the exception of $A l$ Mahdi trial which was completed within less than 1 year (because the accused pleaded guilty), ${ }^{134}$ the trials of Lubanga and Katanga took over 5 years between the confirmation of charges and the convictions. ${ }^{135}$

With staff of over 800 staff members, ${ }^{136}$ the Court's approved annual budget in 2016 was $€ 136,585,100$ and several contributions were outstanding. ${ }^{137}$ As of 15 September 2016 the total outstanding contributions, including the regular budget, the Contingency Fund and interest on the host State loan, stood at $€ 34,163,902 .{ }^{138}$ The growing number of preliminary examinations, investigations and prosecutions would require more resources. The Court's 2017 programme budget was approved at $€ 144,587,300 .{ }^{139}$ Despite such a huge budget, the ICC has been able to convict only non-state actors.

${ }^{130} € 1,479,301,700$ has been spent on the ICC between 2002 and 2016 to secure four convictions only (eight if Article 70 convictions are added). See Statement by the Russian Foreign Ministry on signing the Decree 'On the intention not to become a party to the Rome Statute of the International Criminal Court' (17 November 2016), http://www.rusemb.org.uk/fnapr/5869; D Davenport, 'International Criminal Court: 12 Years, \$1 Billion, 2 Convictions (12 March 2014), http://www.forbes.com/sites/ daviddavenport/2014/03/12/international-criminal-court-12-years-1-billion-2-convic tions-2/\#274232456440. The Court currently has 34 judges and over 700 staff.

${ }^{131}$ The Prosecutor v Bosco Ntaganda, ICC-01/04-02/06.

${ }^{132}$ The Prosecutor v Dominic Ongwen, ICC-02/04-01/15.

133 The Prosecutor v Laurent Gbagbo and Charles Blé Goudé, ICC-02/11-01/15.

134 The Prosecutor v Ahmad Al Faqi Al Mahdi (n 128).

${ }^{135}$ The Prosecutor $v$ Thomas Lubanga Dyilo (n 124); and The Prosecutor v Germain Katanga (n 126).

${ }^{136}$ ICC, Facts and Figures, https://www.icc-cpi.int/about.

${ }^{137}$ Assembly of State Parties, Report of the Committee on Budget and Finance on the work of its twenty-seventh session, ICC-ASP/15/15 (28 October 2016), https://asp. icc-cpi.int/iccdocs/asp_docs/ASP15/ICC-ASP-15-15-ENG.pdf, paras 16(a)-21.

138 Ibid., para 22.

${ }^{139}$ See Resolution of the Assembly of States Parties on the proposed programme budget for 2017, the Working Capital Fund for 2017, the scale of assessment for the apportionment of expenses of the International Criminal Court, financing appropriations for 2017 and the Contingency Fund, ICC-ASP/15/Res.1, at 1. 
The main case against a serving head of state arising out of the UN Security Council referral (Al Bashir of Sudan) stalled primarily due to the Council's failure to put pressure on Sudan to cooperate fully with the Court or to surrender $\mathrm{Al}$ Bashir to the Court, thus undermining the ICC's investigations. ${ }^{140}$ All the five suspects ${ }^{141}$ against whom ICC arrest warrants were issued in the situation in Darfur remain at large in Sudan nearly a decade later after the first warrant was issued primarily due to the Security Council's lack of robust, swift and concrete action after the referral to induce Sudan and other States to execute the arrest warrants. ${ }^{142}$ This has emboldened $\mathrm{Al}$ Bashir to travel to both ICC state and non-state parties as well as emboldening states to continue to host him. ${ }^{143}$ As noted by the ICC Pre-Trial Chamber II:

In the absence of follow-up actions on the part of the Security Council, any referral to the Court under Chapter VII of the United Nations Charter would become futile and incapable of achieving its ultimate goal of putting an end to impunity. ${ }^{144}$

Cases arising out of the exercise of the Prosecutor's proprio motu powers in Kenya have been met by fierce resistance in the form of non-cooperation and witness interference (leading to the withdrawal or vacation of charges against senior State officials - Uhuru Muigai Kenyatta and William Samoei Ruto of Kenya). ${ }^{145}$ Nevertheless, it

${ }^{140}$ See UN Security Council, Reports of the Secretary-General on the Sudan and South Sudan, UN Doc S/PV.7337 (12 December 2014), 2.

${ }^{141}$ The suspects are Omar Hassan Ahmad Al Bashir, Ahmad Muhammad Harun, Ali Muhammad Ali Abd-Al-Rahman, Abdel Raheem Muhammad Hussein and Abdallah Banda Abakaer Nourain.

${ }^{142}$ See Twenty-fourth report of the Prosecutor of the International Criminal Court to the United Nations Security Council pursuant to UNSCR 1593 (2005), 13 December 2016, https://www.icc-cpi.int/itemsDocuments/161213-otp-rep-24-darfur_ Eng.pdf.

143 Ibid., paras 9-22.

${ }^{144}$ The Prosecutor v Omar Hassan Ahmad Al Bashir, ICC-02/05-01/09, 11 July 2016, Decision on the non-compliance by the Republic of Uganda with the request to arrest and surrender Omar Al-Bashir to the Court and referring the matter to the United Nations Security Council and the Assembly of State Parties to the Rome Statute, para 16. See also Decision on the non-compliance by the Republic of Djibouti with the request to arrest and surrender Omar Al-Bashir to the Court and referring the matter to the United Nations Security Council and the Assembly of the State Parties to the Rome Statute, ICC-02/05-01/09, 11 July 2016 para 17.

${ }^{145}$ See The Prosecutor v Uhuru Muigai Kenyatta, (n 117); and The Prosecutor $v$ William Samoei Ruto and Joshua Arap Sang (n 117). 
must be acknowledged that during its first 16 years the ICC has established itself as a functioning institution with investigations, arrests, trials, convictions, acquittals and appeals. As at the time of writing in January 2017, the Court had three trials running, one of which was expected to be completed in 2018 and the other two in 2019 but there were no cases at the pre-trial stage. ${ }^{146}$

An increase in the number of situations and cases before the ICC means that that there will be an increase in the Court's workload/ activities (e.g. outreach and public information, investigations, legal aid for victims and accused, trial preparation, funds for victims) and long-term spending pattern of the ICC over the years. ${ }^{147}$ Unlike other international criminal tribunals created in recent decades with limited temporal and geographical jurisdiction, ${ }^{148}$ the ICC is a permanent court whose membership has been growing over the years. This requires increased prioritisation in the exercise of prosecutorial discretion and improvement in the quality and efficiency of the Court's core activities including preliminary examinations, investigations, analysis, trials and appeals. ${ }^{149}$

\subsection{UN Security Council's Failure to Defer Investigation or Prosecu- tion}

Another reason advanced by South Africa for its withdrawal notification from the Rome Statute is that: 'The Security Council has also not played its part in terms of Article 16 of the Rome Statute where the involvement of the ICC will pose a threat to peace and security on

${ }^{146}$ See The Prosecutor $v$ Dominic Ongwen, ICC-02/04-01/15; The Prosecutor $v$ Laurent Gbagbo and Charles Blé Goudé, ICC-02/11-01/15; The Prosecutor v Bosco Ntaganda, ICC-01/04-02/06.

147 S Ford, 'How Much Money Does the ICC Need?' in Stahn (n 86) 84-104.

148 Such tribunals include: the International Tribunal for the Prosecution of Persons Responsible for Serious Violations of International Humanitarian Law Committed in the Territory of the Former Yugoslavia; International Criminal Tribunal for Rwanda; the Extraordinary Chamber in the Courts of Cambodia; and the Special Court for Sierra Leone. See S Ford, 'How Leadership in International Criminal Law is Shifting from the United States to Europe and Asia: An Analysis of Spending on and Contributions to International Criminal Courts' (2011) 55 Saint Louis University Law Journal 953.

149 See Office of The Prosecutor, Policy Paper on Case Selection and Prioritisation (15 September 2016) https://www.icc-cpi.int/itemsDocuments/20160915_OTP-Pol icy_Case-Selection_Eng.pdf; The Report of the Court on the Basic Size of the Office of the Prosecutor, ICC-ASP/14/21 (17 September 2015). 
the African continent'. ${ }^{150}$ Although South Africa did not provide further details, its claim is based on the failure of the UN Security Council to defer situations in Darfur and Kenya with specific reference to cases arising from those situations concerning some prosecution of African heads of state. In 2008 when the ICC Prosecutor announced that he was seeking an arrest warrant against President Al Bashir of Sudan, the AU called upon the Security Council to apply Article 16 of the Rome Statute and 'defer the process [proceedings] initiated by the ICC' for a period of 12 months. ${ }^{151}$

A similar request was made in 2013 to defer the investigation and prosecution against Kenya's President Uhuru Muigai Kenyatta and Deputy President William Samoei Ruto. ${ }^{152}$ However, the Security Council did not adopt any resolution on the basis of Article 16 to defer investigations/prosecutions in both Darfur and Kenya. ${ }^{153}$ Article 16 of the Rome Statute provides for the deferral of investigation or prosecution by the UN Security Council when political and conflict resolution imperatives (the maintenance of international

${ }^{150}$ Declaratory Statement (n 27).

${ }^{151}$ See, eg, African Union Peace and Security Council Decision, PSC/MIN/Comm (CXLII), 21 July 2008 paras 3, 5, 9, 11(i); African Union Peace and Security Council Decision, PSC/PR/Comm (CLXXV), 5 March 2009, paras 4-6; African Union Decision on the Application by the ICC Prosecutor for the Indictment of the President of the Republic of the Sudan, Dec.221(XII), 3 February 2009, paras 2-3; African Union Decision on the Meeting of the African States Parties to the Rome Statute of the International Criminal Court (ICC), Doc.Assembly/AU/13(xiii), Assembly/AU/Dec.245(XIII) Rev.1, 1-3 July 2009, para 9; Decision on the Implementation of the Decisions on the International Criminal Court, Doc. EX.CL/ 639(XVIII), Assembly/AU/Dec.334(XVI), 30-31 January 2011, para 3.

${ }^{152}$ See, eg, Decision on the Progress Report of the Commission on the Implementation of Previous Decisions on the International Criminal Court (ICC) - Doc. Assembly/AU/18(XXIV), Assembly/AU/Dec.547(XXIV), 30-31 January 2015, paras 3 and 17(d); Decision on the International Criminal Court Doc. EX.CL/ 952(XXVIII),Assembly/AU/Dec.590(XXVI), 30-31 January 2016, para 2(ii); Decision on the Implementation of the Decisions on the International Criminal Court (ICC) - Doc. EX.CL/639(XVIII),Assembly/AU/Dec.334(XVI), 30-31 January 2011, para 6; Decision on the Implementation of the Decisions on the International Criminal Court (ICC) - Doc. EX.CL/731(XXI),Assembly/AU/Dec.419 (xix), 15-16 July 2012, para 4; Decision on Africa's Relationship with the International Criminal Court (ICC), Ext/Assembly/AU/Dec.1 (October 2013) para 10(i), (ii), (xi); UNSC Draft Resolution Seeking Deferral of Kenyan Leaders' Trial Fails to Win Adoption, with 7 Voting in Favour, 8 Abstaining, SC/11176 (15 November 2013), http://www. un.org/press/en/2013/sc11176.doc.htm.

${ }^{153}$ See UN Doc. S/RES/1828 (2008); UN Doc. S/PV.7060, p. 2. 
peace and security) would make it necessary to delay international criminal justice (ICC investigation or prosecution). Article 16 reads:

No investigation or prosecution may be commenced or proceeded with under this Statute for a period of 12 months after the Security Council, in a resolution adopted under Chapter VII of the Charter of the United Nations, has requested the Court to that effect; that request may be renewed by the Council under the same conditions.

Under Chapter VII of the UN Charter the Security Council is empowered to 'determine the existence of any threat to the peace, breach of the peace, or act of aggression' and to make recommendations, or decide what measures shall be taken to 'maintain or restore international peace and security'. ${ }^{154}$ The travaux préparatoires of Article 16 indicates that the relationship between the Court and the Security Council was very contentious. ${ }^{155}$ The content of the current Article 16 of the Rome Statute was introduced by Singapore ${ }^{156}$ as a means of ensuring that 'politically motivated actions [referrals] by States Parties or by the Prosecutor that might contradict Security Council aims could be suspended or terminated indefinitely by the Security Council acting under its Chapter VII authority'. ${ }^{157}$ It was thus intended to be used on 'a case-by-case basis by reference to particular situations, so as to enable the Security Council to advance the interests of peace where there might be a temporary conflict between the resolution of armed conflict, on the one hand, and the prosecution of offences, on the other'. ${ }^{158}$ It was not intended to defer situations referred by the Security Council and the cases that arise from it since the Council has established that international criminal prosecutions contribute to the 'restoration and maintenance of peace'. ${ }^{159}$ Despite its adoption,

${ }^{154}$ UN Charter (n 49), Art 39.

${ }^{155}$ Clark (n 7), 770-780.

${ }^{156}$ See Proposal by Singapore on article 23, Non-Paper/WG. 3/No. 16 (8 August 1997).

${ }^{157}$ D Scheffer, 'Three Realities About African Situation at the International Criminal Court' ICC Forum (November 2016), http://iccforum.com/withdrawal.

${ }^{158}$ See UN Security Council, 4568th Meeting, 10 July 2002, statement by Permanent Representative of New Zealand, Mr. MacKay, UN Doc S/PV.4568, p. 5, http://www.un.org/Docs/pv4568e.pdf.

159 See, eg, UN Security Council Resolution 808 (1993), S/RES/808, 22 February 1993, preamble para 9; UN Security Council Resolution 827 (1993), S/RES/827, 25 May 1993, preamble, para 6; and UN Security Council Resolution 955 (1994), S/RES/955, 8 November 1994, preamble para 7. 
many states considered that it was an unacceptable encroachment upon judicial independence. As yet, the Court has not yet interpreted the scope of Article 16 but the Security Council has used it in two resolutions to protect officials or personnel of the Security Council members and their close allies. ${ }^{160}$

Following the failure of the UN Security Council to defer the investigations or prosecutions in African situations in particular those relating to heads of states in Darfur/Sudan and Kenya, as requested by the AU, South Africa, acting on behalf of AU State Parties to the Rome Statute, proposed, some amendments to the Statute. This was made in accordance with Article 121(1) of the Rome Statute. It specifically proposed an amendment to Article 16 in order to allow the UN General Assembly to exercise deferral powers when the Security Council fails to act. ${ }^{161}$ South Africa's proposal provided for the addition of the following paragraphs to the current Article 16:

(2) A State with jurisdiction over a situation before the Court may request the UN Security Council to defer the matter before the Court as provided for in (1) above. (3) Where the UN Security Council fails to decide on the request by the state concerned within six (6) months of receipt of the request, the requesting Party may request the UN General Assembly to assume the Security Council's responsibility under paragraph 1 consistent with Resolution 377 (v) of the UN General Assembly. ${ }^{162}$

The above proposal was not adopted since it raised several questions with regard to the relationship between the UN Security Council and the UN General Assembly as well as the relationship between the ICC and the UN. ${ }^{163}$

\subsection{Conflicting International Law Obligations}

Another reason advanced for South Africa's withdrawal notification from the ICC is that the Rome Statute has been interpreted in a

${ }^{160}$ See SC Resolution 1422 (12 July 2002), UN Doc S/RES/1422 (2002); SC Resolution 1487 (12 June 2003) UN Doc S/RES/1487 (12 June 2003); Amnesty International, 'The Unlawful Attempt by the Security Council to give US Citizens permanent Impunity from International Justice', AI Index IOR 40/006/2003 (May 2003).

${ }^{161}$ Report of the Working Group on the Review Conference, ICC-ASP/8/20, Annex II, para 59.

${ }^{162}$ UN Depositary Notification C.N.851.2009.TREATIES-10 of 30 November 2009 (South Africa: Proposal of Amendment).

${ }^{163}$ Report of the Working Group on Amendments, ICC-ASP/13/31, para 9 and ICC-ASP/14/34, para 17. 
manner that has led to 'conflicting international law obligations'. ${ }^{164}$ In particular, South Africa's Minister of Justice stated that the Rome Statute compel ICC state parties including South Africa to 'arrest persons who may enjoy diplomatic immunity under customary international law who are wanted by the court'. ${ }^{165}$ In effect the claim here is that compliance with the Rome Statute would lead to a breach of obligations to other states. The alleged obligations relate to whether or not a head of state non-party to the Rome Statute (in particular, President Al Bashir of Sudan subject to two ICC arrest warrants for crimes against humanity and genocide) enjoys immunities ratione personae from arrest and surrender to the ICC. ${ }^{166}$

On 4 March 2009, ICC Pre-Trial Chamber I (composed of Judge Akua Kuenyehia, Presiding Judge, Judge Anita Usacka, and Judge Sylvia Steiner) stated that 'the current position of Omar Al Bashir as Head of a state which is not a party to the Statute, has no effect on the Court's jurisdiction over the present case'. ${ }^{167}$ This determination was based on four considerations namely the goal of ending impunity for the perpetrators of the most serious crimes as stated in the Rome Statute's preamble; Article 27 of the Statute; the law applicable was the Rome Statute, Elements of Crimes and its Rules of Procedure and Evidence; and the effect of the Security Council. ${ }^{168}$ The Chamber stated that:

...by referring the Darfur situation to the Court, pursuant to article 13(b) of the Statute, the Security Council of the United Nations has also accepted that the investigation into the said situation, as well as any prosecution arising therefrom, will take place in accordance with the statutory framework provided for in the Statute, the Elements of Crimes and the Rules as a whole. ${ }^{169}$

The Chamber decided that the Registry 'prepare a request for cooperation seeking the arrest and surrender of Omar Al Bashir' to the ICC. Accordingly the Registry requested all ICC state parties to

${ }^{164}$ See South Africa's 'Declaratory statement' (n 27), 2.

${ }^{165}$ See South African Government News Agency, 'SA Formally Withdrawing from ICC' 21 October 2016, http://www.sanews.gov.za/south-africa/sa-formallywithdrawing-icc.

166 See Pre-Trial Chamber I (n 17).

167 The Prosecutor v Omar Hassan Ahmad Al Bashir, ICC-02/05-01/09-3 (4 March 2009), Decision on the Prosecution's Application for a Warrant of Arrest against Omar Hassan Ahmad Al Bashir, para 41.

168 Ibid., paras 42-45.

169 Ibid., para 45. 
arrest and surrender $\mathrm{Al}$ Bashir. ${ }^{170}$ This was done without considering whether such a request would, under Article 98 of the Rome Statute, be inconsistent with the requested state's obligations under (customary) international law with respect to the head of state immunity of Al Bashir.

Following the failure of some ICC state parties to arrest President Al Bashir on numerous international visits to African ICC States parties (including Malawi, Chad, Democratic Republic of the Congo (DRC), Kenya, Uganda, Djibouti and South Africa), the ICC PreTrial Chamber interpreted the Rome Statute as imposing an obligation on state parties to arrest Al Bashir because of two reasons.

First, the Chamber rejected the argument presented by Malawi, with respect to states not parties to the Rome Statute, that international law affords immunity to Heads of States in respect of proceedings before international courts'. ${ }^{171}$ It claimed that 'customary international law creates an exception to Head of State immunity when international courts seek a Head of State's arrest for the commission of international crimes'. ${ }^{172}$ Although this position was re-stated in a decision concerning the Republic of Chad, ${ }^{173}$ the Chamber did not provide satisfactory evidence to support this view. ${ }^{174}$ It is correct to state that the immunity for Heads of State before international courts has been rejected time and time again dating all the way back to World War $1{ }^{\prime} .{ }^{175}$ This was the case with the practice of the Nuremberg Tribunals, the Tokyo Tribunals, the

${ }^{170}$ See The Prosecutor v Omar Hassan Ahmad Al Bashir, ICC-02/05-01/09-7, Request to All States Parties to the Rome Statute for the Arrest and Surrender of Omar Al Bashir (11 March 2009); ICC-02/05-01/09-96, Supplementary Request to All States Parties to the Rome Statute for the Arrest and Surrender of Omar Hassan Ahmad Al Bashir (21 July 2010).

${ }^{171}$ The Prosecutor $v$ Omar Hassan Ahmad Al Bashir, ICC-02/05-01/09 (12 December 2011), Decision Pursuant to Article 87(7) of the Rome Statute on the Failure by the Republic of Malawi to Comply with the Cooperation Requests Issued by the Court with Respect to the Arrest and Surrender of Omar Hassan Ahmad Al Bashir (Malawi Decision), para 18.

172 Ibid., para 43.

173 The Prosecutor v. Omar Hassan Ahmad Al Bashir, ICC-02/05-01/09 (13 December 2011), Decision pursuant to article 87(7) of the Rome Statute on the refusal of the Republic of Chad to comply with the cooperation requests issued by the Court with respect to the arrest and surrender of Omar Hassan Ahmad Al Bashir, para 13.

\footnotetext{
${ }^{174}$ See Malawi Decision (n 171), paras 22-43.

175 Ibid., para 38.
} 
ICTY, the ICTR, the Special Court for Sierra Leone and the Lebanon Tribunals. However, there is no evidence to show that this practice is generally 'accepted as law' (opinio juris) in order to transform it into a rule of customary international law, ${ }^{176}$ and none was presented by the ICC in the Malawi and Chad decisions. ${ }^{177}$ Accordingly, it was not proved that customary international law requires or rejects immunity before international courts and tribunals.

Second, the Chamber held that by virtue of the language used in paragraph 2 of Security Council (SC) Resolution 1593(2005), ${ }^{178}$ 'the SC implicitly waived the immunities granted to Omar Al Bashir under international law and attached to his position as a Head of State'. ${ }^{179}$ Thus South Africa was under 'the duty under the Rome Statute to immediately arrest Omar Al-Bashir and surrender him to the Court' during Al Bashir's presence in South Africa. ${ }^{180}$

According to South Africa arresting senior state officials such as African heads of state or ministers who are subject to ICC arrest warrants makes it impossible to participate in the peaceful resolution of conflicts. ${ }^{181}$ Yet negotiation of peace agreements (to end armed conflicts, which so often unleashes serious crimes) may require the participation of African heads of state or senior ministers who are subject of ICC arrest warrants. Accordingly, South Africa claimed that to 'continue to be a State Party to the Rome Statute will

${ }^{176}$ See the Report of the International Law Commission on the Work of its SixtySixth Session (5 May-6 June and 7 July-8 August 2014), General Assembly Official Records Sixty-ninth Session Supplement No. 10 (A/69/10), Chap 10, paras 169-171.

${ }^{177}$ See D Tladi, 'The ICC Decisions in Chad and Malawi: on Cooperation, Immunities, and Article 98' (2013) 11(1) Journal of International Criminal Justice 199.

${ }^{178}$ UN SC Resolution 1593(2005) para 2. The SC decided that the 'Government of Sudan [...] shall cooperate fully with and provide any necessary assistance to the Court and the Prosecutor pursuant to this resolution'.

179 The Prosecutor v Omar Hassan Ahmad Al Bashir, ICC-02/05-01/09 (9 April 2014), Decision on the Cooperation of the Democratic Republic of the Congo Regarding Omar Al Bashir's Arrest and Surrender to the Court, para 29.

${ }^{180}$ The Prosecutor v Omar Hassan Ahmad Al Bashir, ICC-02/05-01/09 (13 June 2015), Decision following the Prosecutor's request for an order further clarifying that the Republic of South Africa is under the obligation to immediately arrest and surrender Omar Al Bashir, para 10.

${ }^{181}$ See South Africa's 'Instrument of Withdrawal', 19 October 2016 (on file with author). 
compromise its efforts to promote peace and security on the African Continent'. 182

The claim here is that the interpretation given to Articles 27 and 98 of the Rome statute compel South Africa (in particular in situations referred to the Court by the Security Council) to arrest persons in South Africa including serving heads of states of foreign states subject to ICC warrants who may enjoy diplomatic immunity under customary international law, and 'to surrender those persons to the International Criminal Court, even under circumstances where the Republic of South Africa is actively involved in promoting peace, stability and dialogue in those countries'. ${ }^{183}$ According to South Africa, 'arrest of such a person by a State Party pursuant to its Rome Statute obligations, may therefore result in a violation of its customary international law obligations' on diplomatic immunity or head of state immunity. ${ }^{184}$ In South Africa's view, this immunity is necessary in order to 'effectively promote dialogue and the peaceful resolution of conflicts wherever they may occur'. ${ }^{185}$

It should be noted that according to Article 25 of the UN Charter the UN members 'agree to accept and carry out the decisions of the Security Council' in accordance with the Charter. ${ }^{186}$ Therefore, 'when the Security Council adopts a decision under article 25 in accordance with the Charter, it is for member States to comply with that decision'. ${ }^{187}$ This includes decisions concerning referrals to the ICC including Council decisions that ICC state parties 'cooperate fully' with the Court. In the event of a conflict between the obligations of the UN members under the UN Charter and their obligations under any other international agreement including the Rome Statute, their obligations under the UN Charter 'shall prevail'. ${ }^{188}$ In effect UN

182 Declaratory Statement (n 27).

${ }^{183}$ Memorandum on the Objects of the Implementation of the Rome Statute of the International Criminal Court Act Repeal Bill, 2016, http://www.parliament.gov. za/live/commonrepository/Processed/20161111/616356_1.pdf, para 1.2.

${ }^{184}$ Declaratory Statement (n 27).

${ }^{185}$ Memorandum (n 183), para 1.3.

${ }^{186}$ UN Charter (n 49), Art 25.

${ }^{187}$ Legal Consequences for States of the Continued Presence of South Africa in Namibia (South West Africa) notwithstanding Security Council Resolution 276 (1970), ICJ Advisory Opinion, 21 June 1971 (1971) ICJ Reports 16, para 116, http:// www.icj-cij.org/docket/files/53/5595.pdf.

${ }^{188}$ UN Charter (n 49), Art 103. 
member states, including non-state parties to the Rome Statute, are by virtue of Articles 25 and 103 of the UN Charter obliged to comply with the decisions of the UN Security Council arising from resolutions of the UN Security Council Chapter VII referral of situations to the ICC.

Does the Rome Statute require ICC state parties to act in a violation of customary international law of immunity to a serving head of state (from arrest and surrender)? Immunity provisions under Articles 27 and 98, interpreted in accordance with the object and purpose of the Rome Statute, do not lead to violation of customary international law. Article 27 aims at eliminating impunity by providing that immunity is not a bar to the Court's jurisdiction:

1. This Statute shall apply equally to all persons without any distinction based on official capacity. In particular, official capacity as a Head of State or Government, a member of a Government or parliament, an elected representative or a government official shall in no case exempt a person from criminal responsibility under this Statute, nor shall it, in and of itself, constitute a ground for reduction of sentence.

2. Immunities or special procedural rules which may attach to the official capacity of a person, whether under national or international law, shall not bar the Court from exercising its jurisdiction over such a person.

The removal of immunity under Article 27 applies to officials of state parties to the Rome Statute and not to non-state parties to the Rome Statute. This is because a 'treaty in force is binding upon the parties to it' and such a treaty 'does not create either rights or obligations for a third state'. ${ }^{189}$ Therefore, Article 98(1) protects state sovereignty by recognising customary international law rules concerning state or diplomatic immunities reflected in an exemption from arrest and surrender of a person or property of a non-state party to the Rome Statute. It provides that:

The Court may not proceed with a request for surrender or assistance which would require the requested State to act inconsistently with its obligations under international law with respect to the State or diplomatic immunity of a person or property of a third State, unless the Court can first obtain the cooperation of that third State for the waiver of the immunity.

${ }^{189}$ Vienna Convention on the Law of Treaties (1980) 1155 UNTS 331, Arts 26 and 34. 
Clearly, Article 98(1) limits the avenues for surrendering individuals or property of a "third state' 190 to the ICC that are entitled to immunity principally under customary international law. ${ }^{191}$

Some African ICC states parties (Malawi, ${ }^{192}$ Chad, $^{193}{ }^{\text {DRC }}{ }^{194}$ and South Africa ${ }^{195}$ ) refused to arrest and surrender President Omar Al Bashir of Sudan during his presence in respective states partly on the basis that complying with the ICC requests would require violation of head of state immunities under customary international law. In its decisions on Malawi and Chad, the ICC Pre-Trial Chamber (composed of Judge Sanji Mmasenono Monageng, Presiding Judge, Judge Sylvia Steiner, and Judge Cuno Tarfusser), in December 2011, accepted that there is 'an inherent tension between articles 27(2) and 98(1) of the [Rome] Statute and the role immunity plays when the Court seeks cooperation regarding the arrest of a Head of State'. ${ }^{196}$ The Chamber went on to observe that Article 98(1) was not applicable because customary international law 'creates an exception to Heads of State immunity when international courts seek a Head of State's arrest for the commission of international crimes'. ${ }^{197}$ The Court stated that the unavailability of immunities with respect to

${ }^{190}$ Ibid., Arts 2(1)(h), 34-38. The term 'third state' means 'a State not a party to the treaty'. In the context of cooperation treaties it is used to refer to a state that is a third party to the cooperation request. Under Article 98 of the Rome Statute a 'third state' could refer to any other state that still has immunities.

${ }^{191}$ For a commentary on Article 98 see WA Schabas, The International Criminal Court: A Commentary on the Rome Statute 2nd edn (Oxford University Press, 2016) 1342-1353, at 1346.

192 Decision Pursuant to Article 87(7) of the Rome Statute on the Failure by the Republic of Malawi to Comply with the Cooperation Requests Issued by the Court with Respect to the Arrest and Surrender of Omar Hassan Ahmad Al Bashir, ICC02/05-01/09-139, Pre-Trial Chamber I, 12 December 2011.

${ }^{193}$ Decision pursuant to article 87(7) of the Rome Statute on the refusal of the Republic of Chad to comply with the cooperation requests issued by the Court with respect to the arrest and surrender of Omar Hassan Ahmad Al Bashir, ICC-02/0501/09, Pre-Trial Chamber I, 13 December 2011.

${ }^{194}$ Decision on the Cooperation of the Democratic Republic of the Congo Regarding Omar Al Bashir's Arrest and Surrender to the Court, ICC-02/05-01/09, Pre-Trial Chamber I, 9 April 2014.

${ }^{195}$ Decision following the Prosecutor's request for an order further clarifying that the Republic of South Africa is under the obligation to immediately arrest and surrender Omar Al Bashir, ICC-02/05-01/09, Pre-Trial Chamber I, 13 June 2015.

${ }^{196}$ Malawi Decision (n 192), para 37.

197 Ibid., paras 42-43. 
prosecution 'applies to cooperation'198 and that to interpret Article 98(1) as allowing the requested states to refuse to arrest and surrender heads of state "would disable the Court and the international criminal justice'. ${ }^{199}$

Despite the above observations, the Court did not give an interpretation of Article 98(1). It, therefore, did not address the 'tension' between Articles 27(2) and 98(1) but based its decision on Article 27, while ignoring completely the need to interpret Article 98(1) as if it was not part of the Rome Statute. If immunity under customary international law does not exist when the ICC seeks arrest of a person entitled to immunity (e.g. a head of a non-state party to the Rome Statute) for the commission of international crimes, then Article 98 is effectively redundant. In 2014 the Pre-Trial Chamber (with two new judges who did not participate in Malawi and Chad decisions) $)^{200}$ attempted to address the scope of Article 98(1) by noting that:

it is not disputed that under international law a sitting Head of State enjoys personal immunities from criminal jurisdiction and inviolability before national courts of foreign States even when suspected of having committed one or more of the crimes that fall within the jurisdiction of the Court. Such personal immunities are ensured under international law for the purpose of the effective performance of the functions of sitting Heads of States. This view has also been supported by the International Court of Justice (the "ICJ"). ${ }^{201}$ An exception to the personal immunities of Heads of States is explicitly provided in article 27(2) of the Statute for prosecution before an international criminal jurisdiction. According to this provision, the existence of personal immunities under international law which generally attach to the official capacity of the person "shall not bar the Court from exercising its jurisdiction over such a person". ${ }^{202}$

The Chamber correctly noted that Article 27(2) should 'in principle, be confined to those State Parties who have accepted it'. ${ }^{203}$ Therefore, the Chamber accepted that "when the exercise of jurisdiction by the Court entails the prosecution of a Head of State of a non-State Party,

\footnotetext{
198 Ibid., para 44.

199 Ibid., para 41.
}

200 The Chamber was composed of Judge Ekaterina Trendafilova, Presiding Judge Judge, Hans-Peter Kaul and Judge Cuno Tarfusser (who participated in the decisions concerning Malawi and Chad).

${ }^{201}$ Case Concerning the Arrest Warrant of 11 April 2000 (Democratic Republic of the Congo v Belgium), Judgment, 14 February 2002 (2002) ICJ Reports 3, paras 5359, http://www.icj-cij.org/docket/files/121/8126.pdf.

202 DRC Decision (n 194), para 25.

203 Ibid., para 26. 
the question of personal immunities might validly arise. The solution provided for in the Statute to resolve such a conflict is found in article 98(1) of the Statute'. ${ }^{204}$ Accordingly, in a case dealing with a head of state not party to the Rome Statute, who is wanted by the ICC, and where there is no relevant Security Council referral or binding treaty removing immunity, immunity ought to continue to be given effect to in the light of the position under customary international law.

However, according to the Chamber, the Security Council 'implicitly waived' the immunities granted to Omar Al Bashir under international law and attached to his position as a head of state by virtue of SC Resolution 1593 (2005) for the purpose of the proceedings before the Court. ${ }^{205}$ It follows that under customary international law, a head of state does not possess immunity in cases where that immunity has been waived or removed either implicitly or explicitly by the Security Council or treaty such as the Genocide Convention $^{206}$ to which a state is a party. Consequently, the Security Council referral has the effect of making the Rome Statute (including Article 27) applicable to non-state parties and removes immunity in that situation. It is essential for the Security Council, when it makes a Chapter VII referral with regards to a situation concerning a nonparty to the Rome Statute, to explicitly waive immunities and to impose clear obligations of cooperation in accordance with the provisions of the Rome Statute on that non-party and ICC state parties. Since the UN Security Council imposed an obligation on Sudan, that Sudan 'shall cooperate fully', presumably that imposes all the coop-

\footnotetext{
${ }^{204}$ Ibid., para 27.
}

205 Ibid., para 29; and South Africa decision (n 195), paras 6-7 (Judge Cuno Tarfusser, Presiding Judge). The Chamber relied on SC Resolution 1593 (2005) para 2 which: 'Decides that the Government of Sudan and all other parties to the conflict in Darfur, shall cooperate fully with and provide any necessary assistance to the Court and the Prosecutor pursuant to this resolution and, while recognizing that States not party to the Rome Statute have no obligation under the Statute, urges all States and concerned regional and other international organizations to cooperate fully'. See also D Akande, 'The Legal Nature of Security Council Referrals to the ICC and its Impact on Al Bashir Immunities' (2009) 7(2) Journal of International Criminal Justice 333-352; D Akande, 'The Effect of Security Council Resolutions and Domestic Proceedings on State Obligations to Cooperate with the ICC' (2012) 10(2) Journal of International Criminal Justice 299-324.

${ }^{206}$ See Convention on the Prevention and Punishment of the Crime of Genocide, 78 UNTS 277, entered into force 12 January 1951, Art IV provides: 'Persons committing genocide ... shall be punished, whether they are constitutionally responsible rulers, public officials or private individuals'. 
eration obligations in part 9 of the Rome Statute. In this regard, the non-state party has an international law obligation to cooperate with the Court arising under the UN Charter. As noted above, this obligation prevails over any other treaty obligation. Therefore, in such a case there is no violation of customary international law immunity (from arrest in states cooperating with the ICC) and thus no conflicting international law obligations arise. State parties to the Rome Statute remain obliged to cooperate with the Court as parties to the Rome Statute, rather than on the basis of the UN Charter.

\section{IMPACT OF THE WITHDRAWAL NOTIFICATIONS BY SOUTH AFRICA, BURUNDI AND THE GAMBIA}

The general effect of withdrawal is that, subject to Article 127(2), a withdrawing state will no longer be a party to and bound by the Rome Statute once withdrawal becomes effective. ${ }^{207}$ As a matter of law, withdrawal has no impact on a withdrawing state obligations (to cooperate with the Court in connection with criminal investigations and proceedings), including any financial obligations which may have accrued, under the Rome Statute prior to the date on which the withdrawal becomes effective. ${ }^{208}$ It follows that breaches of the Rome Statute committed prior to withdrawal on a state's territory (such as South Africa's failure to arrest and surrender Al Bashir) or by a withdrawing state's national would still fall within the Court's jurisdiction notwithstanding the fact that investigations had not yet been concluded and prosecutions had not yet been conducted before the withdrawal. ${ }^{209}$ In this regard the Prosecutor should conclude whether there is a reasonable basis to proceed with an investigation and if so submit to the Pre-Trial Chamber a request for authorisation of an investigation in Burundi formally in good time before 27 October 2017, the effective date of withdrawal. In accordance with Articles 15 and 53 of the Rome Statute, the Pre-Trial Chamber should consider whether to authorise the opening of an investigation in Burundi before the date of withdrawal becomes effective.

Similarly, withdrawal does not affect a state's other obligations under international treaties or customary international law since it is

\footnotetext{
${ }^{207}$ See n 9 above.

${ }^{208}$ Rome Statute (n 1), Art 127(2); Vienna Convention on the Law of Treaties (n 189), Art 70(1)(b).

${ }^{209}$ Clark (n 7), 2324.
} 
settled law that 'the withdrawal of a party from a treaty 'shall not in any way impair the duty of any State to fulfil any obligation embodied in the treaty to which it would be subject under international law independently of the treaty'. ${ }^{210}$ This means that the obligations of South Africa, Burundi and The Gambia as state parties to the Genocide Convention are not affected by withdrawing from the Rome Statute. Withdrawing states still have an 'implicit obligation' to cooperate with a competent 'international penal tribunal' as may have jurisdiction over genocide such as the ICC when it is acting by virtue of a Security Council referral, including an obligation to arrest persons charged with genocide and surrender them to the ICC for trial. ${ }^{211}$

Withdrawal from the ICC intended to avoid accountability may be costly to poorer developing states in terms of its impact on a state's (perceived or real) commitment to international criminal justice. It may lead to retaliatory measures (such as cutbacks in the EU technical and financial assistance or international assistance/development aid). ${ }^{212}$ Thus, the withdrawal notifications of three African states have prompted strong statements of support for the Court from a greater number of African states. State officials of several African ICC state parties - including Botswana, Burkina Faso, Cape Verde, Côte d'Ivoire, DRC, Ghana, Ivory Coast, Lesotho, Malawi, Mali, Nigeria, Senegal, Sierra Leone, Tanzania, Tunisia, and Zambia have reaffirmed their continuous commitment to support and cooperate with the ICC. ${ }^{213}$

African state parties to the Rome Statute are thus widely divided on the AU's so-called 'ICC Withdrawal Strategy', which does not really focus on withdrawal but mainly contains constructive non-

${ }^{210}$ Vienna Convention on the Law of Treaties (n 189), Art 43.

${ }^{211}$ Genocide Convention (n 206), Art VI; Application of the Convention on the Prevention and Punishment of the Crime of Genocide (Bosnia and Herzegovina $v$ Serbia and Montenegro), Judgment of 26 February 2007 (2007) ICJ Reports 43, http://www. icj-cij.org/docket/files/91/13685.pdf, paras 439-447.

${ }^{212}$ See The European Union and the International Criminal Court (February 2008), https://www.consilium.europa.eu/uedocs/cmsUpload/ICC_internet08.pdf, 16.

${ }^{213}$ SR Lansky, Africans Speak Out Against ICC Withdrawal: Governments Signal Continued Support for Court, 2 November 2016, https://www.hrw.org/news/2016/11/ 02/africans-speak-out-against-icc-withdrawal; E Keppler, 'African Members Reaf firm Support at International Criminal Court Meeting: Countries Commit to Working Within the ICC System', 17 November 2016, https://www.hrw.org/news/ 2016/11/17/african-members-reaffirm-support-international-criminal-court-meeting. 
legally binding ICC reform proposals. ${ }^{214}$ For example, in January 2017 Nigeria, Senegal, and Cape Verde formally entered reservations to the AU decision adopted by heads of state which fully supported 'the sovereign decisions taken by Burundi, South Africa and The Gambia as pioneer implementers of the [AU's ICC] Withdrawal Strategy'. ${ }^{215}$ Liberia entered a reservation to the paragraph that 'adopts the ICC Withdrawal Strategy' while Malawi, Tanzania, Tunisia and Zambia 'requested more time to study the Withdrawal Strategy'. ${ }^{216}$ Other non-African states including Canada, Switzerland, Slovenia, and Czech Republic have affirmed strong support for the ICC's mission following South Africa's withdrawal notification. ${ }^{217}$ The result of withdrawals could be a Court membership that is slightly smaller in number but more committed to cooperation with the ICC.

However, it must be noted that withdrawals represent a loss to the Court and to the victims it serves by limiting the Court's ability to investigate and prosecute any future international crimes after the withdrawal notices come into effect. This is because withdrawing states will no longer be bound by the Rome Statute including the obligation to 'cooperate with the ICC and to arrest and surrender to the Court persons in respect of whom the ICC has issued an arrest warrant and a request for assistance'. ${ }^{218}$ Withdrawals would strip victims of one of the most important judicial institutions with a potential to investigate and prosecute international crimes and potentially allow such crimes to be committed by state officials with impunity in the future. African victims continue to rely on the ICC to investigate crimes committed by senior state officials. For example, on 9 December 2016 some Members of Parliament in Uganda called

${ }^{214}$ Decision on the International Criminal Court Doc. EX.CL/1006(XXX) (n 8), para 8 'calls on member states to consider implementing its recommendations'. See also AU, Withdrawal Strategy Document (n 8). The Strategy presents a list of proposed reforms to the Rome Statute and the Court including amendments to the Rome Statute; reform of the UN Security Council; ratification of the Malabo Protocol; increasing African representation in the ICC; strengthening national criminal justice mechanisms; and more engagement with relevant organs - Assembly of State Parties, Office of the Prosecutor and the UN Security Council.

${ }^{215}$ Decision on the International Criminal Court Doc. EX.CL/1006(XXX) (n 8), para 6.

${ }^{216}$ Ibid., para 8.

${ }^{217}$ R Dicker, 'Defend the Integrity of the Rome Statute and a Court Worth Having' Human Rights and International Criminal Law, http://iccforum.com/with drawal\#Dicker.

${ }^{218}$ Minister of Justice v SALC (n 19), para 61. 
for an ICC investigation into the deaths of over 100 people that allegedly occurred when the Ugandan state security agencies (army and police) raided the region's cultural kingdom, 'Obusinga bwa Rwenzururu' king's palace in Rwenzori sub-region - Kasese in Western Uganda on 27 November 2016 and clashed with the Kingdom's royal guards. ${ }^{219}$ Situations for withdrawing states could then only be brought before the Court if the a relevant state decides to accept ICC jurisdiction on an ad hoc basis (which is unlikely in situations where government officials are likely to be investigated) or the UN Security Council makes a referral.

Furthermore, withdrawal notifications of South Africa, Burundi and the Gambia have set a precedent for other African and other states opposed to the ICC to consider withdrawing, or threaten to withdraw from the Court's jurisdiction in the future. ${ }^{220}$ It also creates some doubt among other states considering a possibility of signing and ratifying the Rome Statute not to do so in the near future. Burundi's withdrawal notification specifically provides a way for ICC state parties being (or about to be) investigated by the ICC to resist accountability for genocide, war crimes, crimes against humanity and aggression by initiating a process of withdrawing from the Rome Statute. This is likely to be the case if there are no sustained diplomatic, political or financial costs to withdrawing from the Rome Statute. This is particularly the case whenever state officials are opposed to being investigated for possible international crimes. This is confirmed by President Rodrigo Duterte of the Philippines consideration of withdrawing from the Rome statute to avoid investigations relating to reported extra-judicial killings of alleged drug dealers and users in the Philippines. ${ }^{221}$

${ }^{219}$ E Biryabarema. "Ugandan MPs Petition ICC to Probe Kasese "Genocide"" The East African, 5 January 2016, http://www.theeastafrican.co.ke/news/UgandaMPs-petition-ICC-to-probe-Kasese-genocide/2558-3507338-vic0kiz/index.html; Human Rights Watch, Uganda: 'Investigate Killings in Rwenzori Region: Cycles of Violence, Reprisals Need Justice', 28 November 2016, https://www.hrw.org/news/2016/11/28/ uganda-investigate-killings-rwenzori-region.

${ }^{220}$ Decision on the International Criminal Court Doc. EX.CL/1006(XXX) (n 8), para 8.

${ }^{221}$ ICC, Statement of the Prosecutor of the International Criminal Court, Fatou Bensouda Concerning the Situation in the Republic of the Philippines, 13 October 2016, https://www.icc-cpi.int/Pages/item.aspx?name = 161013-otp-stat-php; K Forster, 'Philip pines May Withdraw from the International Criminal Court, says President Rodrigo' Independent, 17 November 2016, http://www.independent.co.uk/news/world/philippinespresident-rodrigo-duterte-says-they-may-withdraw-from-the-international-criminal- 
Withdrawal is also likely to be an option following a state party's failure to cooperate with the Court in the execution of arrest warrants. For instance following Uganda's non-compliance with the request for arrest and surrender of Al-Bashir to the ICC while he was present on Uganda's territory, ${ }^{222}$ President Museveni publicly referred to the ICC as 'a bunch of useless people ${ }^{223}$ and a 'very useless' institution. ${ }^{224}$ This has been followed by an open consideration of the possibility of withdrawing from the Rome Statute. ${ }^{225}$ However, this rhetoric is limited to the ICC's investigations and prosecutions of serving African leaders. It does not extend to investigating and prosecuting non-state actors. It is in this context that there is apparent good cooperation provided by Uganda in the ongoing ICC trial in the Ongwen case. ${ }^{226}$

Footnote 221 continued court-a7422076.html; NJ Morales and S van den Berg 'Philippines' Duterte says may follow Russia's withdrawal from 'useless' ICC' Reuters, 17 November 2016, http:// www.reuters.com/article/us-philippines-duterte-icc-idUSKBN13C0GS.

${ }^{222}$ The Prosecutor v Omar Hassan Ahmad Al Bashir, Decision on the non-compliance by the Republic of Uganda with the request to arrest and surrender Omar AlBashir to the Court and referring the matter to the United Nations Security Council and the Assembly of State Parties to the Rome Statute, ICC-02/05-01/09 (11 July 2016).

${ }^{223}$ See 'ICC a Bunch of Useless People - Museveni' New Vision, 12 May 2016, http://www.newvision.co.ug/new_vision/news/1424384/icc-bunch-useless-people-mu seveni.

${ }^{224}$ See 'Museveni Praises South Africa's Decision to Leave ICC as he Arrives in Zambia for Uhuru Celebrations', Lusaka Times, 23 October 2016, https://www.lusa katimes.com/2016/10/23/museveni-praises-south-africas-decision-leave-icc-arrives-zam bia-uhuru-celebrations/; E Buchanan, 'Ugandan President Museveni praises African nations for withdrawing from 'useless' ICC' International Business Times, 26 October 2016, http://www.ibtimes.co.uk/ugandan-president-museveni-praises-african-nationswithdrawing-useless-icc-1588328.

${ }^{225}$ See Agencies, 'Uganda's Withdrawal from ICC will Depend on AU Decision', Daily Monitor, 17 November 2016, http://www.monitor.co.ug/News/National/ Uganda-ICC-will-depend-AU-decision/688334-3455476-3cofhaz/index.html.

${ }^{226}$ See The Prosecutor v Dominic Ongwen, ICC-02/04-01/15; ICC, 'ICC President meets with President of Uganda', ICC-CPI-20170302-PR1279 (2 March 2017), https://www.icc-cpi.int//Pages/item.aspx?name $=$ PR1279. 
A few other African ICC state parties in particular Namibia ${ }^{227}$ and Kenya ${ }^{228}$ have considered the option to withdraw from the Rome Statute due to the ICC's alleged bias against African leaders. ${ }^{229}$ President Uhuru Kenyatta has observed that the ICC 'has become a tool of global power politics and not the justice it was built to dispense. ${ }^{230}$ Although there is no evidence to support this view, Russia has supported African states withdrawal notifications by noting that 'the Court [ICC] failed to meet the expectations to become a truly independent, authoritative international tribunal'. ${ }^{231}$ However, as noted in Section 2.2, the ICC remains an independent judicial institution though its credibility is undermined by the practice of the Security Council. While it is difficult to claim that there is a single case at the ICC that should not have been investigated by the Prosecutor, there are many situations that should have been referred to the ICC but they have not been referred.

In addition, South Africa's withdrawal notification led to developments in diplomatic mechanisms. The first step was taken at the meeting of the ICC Assembly of States Parties (ASP) in 2016. At South Africa's request, the ASP Bureau established an open-ended working group to develop consultation mechanisms on the implementation of Article 97 of the Rome Statute. ${ }^{232}$ These are intended to be used when a Member State is subject to an ICC obligation to arrest and surrender to the ICC a serving State official who the State

${ }^{227}$ S Immanuel, 'Cabinet affirms ICC withdrawal' 24 November 2015, The Namibian, http://www.namibian.com.na/index.php?page $=$ archive-read\&id $=144660$; C Milhench, 'Namibia Will Stay in ICC - if United States Joins, Says President' Reuters, 1 December 2016 http://www.reuters.com/article/us-namibia-economy-pre sident-idUSKBN13Q5L0.

${ }^{228}$ See 'Kenya Votes to Leave the ICC Days before Deputy President's Hague Trial' The Guardian (5 September 2013), https://www.theguardian.com/world/2013/ sep/05/kenya-icc-international-criminal-court.

${ }^{229}$ See 'Kenyatta Considers Kenya's ICC Withdrawal, Warns against Foreign Interference' Africa Times, 12 December 2016, http://africatimes.com/2016/12/12/ kenyatta-considers-kenyas-icc-withdrawal-warns-against-foreign-interference/.

${ }^{230}$ Ibid.

${ }^{231}$ See The Ministry of Foreign Affairs of the Russian Federation, 'Statement by the Russian Foreign Ministry', 16 November 2016, http://www.mid.ru/en/foreign_ policy/news/-/asset_publisher/cKNonkJE02Bw/content/id/2523566.

${ }^{232}$ Report of the Chair of the working group of the Bureau on the implementation of article 97 of the Rome Statute of the International Criminal Court, ICC-ASP/15/ 35, 24 November 2016. 
considers to be protected by immunities under international law. ${ }^{233}$ If effectively developed, such mechanisms could be used to clarify the procedure to be followed by the Chamber pursuant to Article 98(1) or (2) as to whether a conflict of obligation indeed exists and whether the Court should indeed not proceed with its request. This has the potential to prevent future perceived or real conflict of obligations like those advanced by South Africa following Al Bashir's visit to South Africa.

Furthermore, following South Africa's withdrawal notification, without prior parliamentary approval, the High Court of South Africa declared the notification 'unconstitutional and invalid' and ordered the responsible government officials ${ }^{234}$ to 'revoke the notice of withdrawal'. ${ }^{235}$ To comply with the above judgment, the Government of South Africa revoked with immediate effect its notification of withdrawal on 7 March 2017, signalling possibly that South Africa does not intend at present to proceed with its withdrawal. ${ }^{236}$ As such, a new notification is required, after obtaining prior parliamentary approval, to restart the 12-month withdrawal period provided for under Article 127(1) of the Rome Statute. In the absence of a new notification of withdrawal by the Government of South Africa, the High Court judgment will, at the very least, delay the timeline for withdrawal. This provides an opportunity to renew South Africa's commitment to the principles and values upheld by the Rome Statute.

Importantly, the non-cooperation proceedings against South Africa at the ICC afford an opening for judicial clarification of the immunity provisions of the Rome Statute, Articles 27 and $98 .{ }^{237}$ These Articles have thus far been interpreted in an unsatisfactory and

${ }^{233}$ See Section 2.4 above.

${ }^{234}$ The Minister of International Relations and Cooperation, the Minister of Justice and Correctional Services and the President of the Republic of South Africa.

${ }^{235}$ Democratic Alliance v Minister of International Relations and Cooperation and Others, Case No 83145/2016 (High Court of South Africa, 22 February 2017).

${ }^{236}$ United Nations, South Africa: Withdrawal of Notification of Withdrawal, C.N.121.2017.TREATIES-XVIII.10, 7 March 2017.

${ }^{237}$ Al Bashir case: ICC Pre-Trial Chamber II Schedules a Hearing on South Africa's Cooperation on 7 April 2017, ICC-CPI-20161208-PR1264, 8 December 2016, https://www.icc-cpi.int/Pages/item.aspx?name $=$ PR1264. These proceedings will consider "whether South Africa failed to comply with its obligations under the [Rome] Statute by not arresting and surrendering Omar Al Bashir to the Court while he was on its territory'. 
inconsistent manner. ${ }^{238}$ If the ICC can more convincingly address the issue of immunities through consistent and satisfactory judicial means, taking into account the concerns of South Africa and other member States, this could address concerns raised by South Africa and render withdrawal unnecessary or unjustifiable. This would prevent other states with similar concerns raised by South Africa from considering future withdrawals and instead focus on cooperation and meaningful engagement with the ICC.

Finally, withdrawals are likely to be followed by the repeal of domestic legislation (e.g. the South African Implementation of the Rome Statute of the International Criminal Court 2002), which gives domestic effect to the Rome Statute. ${ }^{239}$ The repeal of ICC domestic implementing legislation constitutes a form of parliamentary approval for withdrawal from the Rome Statute. This is because after withdrawing from the Rome Statute, concerned states will no longer be under a legal obligation to give effect to the domestication of the provisions of the Rome Statute into national law to ensure that such law became compatible with the Statute. Should this take place, without adopting new legislation for domestic investigation and prosecution of international crimes, an important legal basis for the domestic prosecution of international crimes would be seriously weakened. It will be more difficult to get the full cooperation from withdrawing states in new situations and cases after withdrawals have taken effect.

\section{AFRICAN COURT ON HUMAN AND PEOPLES' RIGHTS: AN ALTERNATIVE TO THE INTERNA- TIONAL CRIMINAL COURT?}

In principle, a case being genuinely investigated or prosecuted by a lawfully constituted regional, sub-regional or bilateral tribunal or court may be regarded as being investigated or prosecuted by a State which has jurisdiction over it' and thus inadmissible before the

${ }^{238} \mathrm{C}$ Kreß, 'The International Criminal Court and Immunities under International Law for States Not Party to the Court's Statute' in M Bergsmo and L Yan (eds), State Sovereignty and International Criminal Law (Torkel Opsahl Academic EPublisher) 223-265.

${ }^{239}$ See Implementation of the Rome Statute of the International Criminal Court Act Repeal Bill, B23-2016, http://www.gov.za/sites/www.gov.za/files/b23-2016_im plementation_of_rome_statute_act_repeal_161103.pdf. 
ICC. ${ }^{240}$ Although the ICC is 'complimentary to national criminal jurisdictions', ${ }^{241}$ nothing in the Rome Statute prevent states from acting collectively at regional, sub-regional or bilateral levels to establish effective criminal tribunals or courts to genuinely carry out investigations and prosecutions of international crimes. Following South Africa's withdrawal notification from the Rome Statute, a statement was issued by South African Ministry of Justice and Correctional services explaining that after withdrawing from the Rome Statute:

South Africa will work closely with the African Union and with other countries in Africa to strengthen continental bodies, such as the African Court on Human and Peoples' Rights, created to deal with such crimes [crimes against humanity and other serious crimes] and to prosecute the perpetrators, whilst at the same time continuing to participate and honour its commitments under international human rights instruments. ${ }^{242}$

The above position is misleading since the African Court on Human and Peoples' Rights does not have temporal, personal and subjectmatter jurisdiction over international crimes such as genocide, war crimes, crimes against humanity and aggression. At the time of writing, there was no operational regional, sub-regional or even bilateral court in Africa with jurisdiction over international crimes. The jurisdiction of the African Court on Human and Peoples' Rights is explicitly limited by the Court's founding treaty to determining human rights cases and disputes submitted to the Court concerning the interpretation and application of the African Charter on Human and Peoples' Rights, ${ }^{243}$ the Protocol establishing this Court and any other relevant human rights instrument ratified by the States concerned. ${ }^{244}$

${ }^{240}$ Rome Statute (n 1), Art 17(1)(a); M Jackson, 'Regional Complementarity: The Rome Statute and Public International Law (2016) 14(4) Journal of International Criminal Justice 1061.

${ }^{241}$ Rome Statute (n 1), Preamble para 10 and Art 1.

${ }^{242}$ See M Masutha, 'Minister Michael Masutha on the matter of International Criminal Court and Sudanese President Omar Al Bashir', 21 October 2016, http:// www.politicsweb.co.za/politics/why-were-withdrawing-from-the-icc-mike-masutha.

${ }^{243}$ African Court on Human and Peoples' Rights, adopted 27 June 1981, OAU Doc. CAB/LEG/67/3 rev. 5, 21 ILM 58 (1982).

${ }^{244}$ Protocol to the African Charter on Human and Peoples' Rights on the Establishment of an African Court on Human and Peoples' Rights, adopted 10 June 1998, OAU Doc. OAU/LEG/EXP/AFCHPR/PROT (III), art 3. 
Thus, given its explicit limited subject-matter jurisdiction, the African Court on Human and Peoples' Rights cannot be a regional alternative to the ICC. Similarly, it cannot be a court that is complementary to the ICC since it cannot conduct criminal investigations and prosecutions on behalf of any state party to the Rome Statute. If South Africa meant strengthening the yet-to-be-established African Court of Justice and Human and Peoples' Rights, this Court does not justify withdrawing from the Rome Statute. Although the new African Court will have three chambers dealing respectively with international crimes, ${ }^{245}$ inter-state disputes and human rights, ${ }^{246}$ it will still not be an effective alternative (or even complementary) to the ICC with respect to serving senior state officials for three reasons.

First, unlike Article 27 of the Rome Statute (and the practice of several international criminal tribunals) ${ }^{247}$ which removes immunities of heads of states parties to the Rome Statute and other senior state officials when the ICC investigates, prosecutes or tries an accused, the African Court of Justice and Human and Peoples' Rights will not have jurisdiction over serving heads of state or senior state officials. Article 46A bis of the African Court of Justice Court Protocol explicitly protects immunity in the following terms:

No charges shall be commenced or continued before the Court against any serving AU Head of State or Government, or anybody acting or entitled to act

${ }^{245}$ See Protocol on Amendments to the Protocol on the Statute of the African Court of Justice and Human Rights (Malabo Protocol), adopted 27 June 2014, http://www.au.int/en/treaties/protocol-amendments-protocol-statute-african-courtjustice-and-human-rights, Arts 28A-28M; G Werle \& M Vormbaum (eds), The African Criminal Court: A Commentary on the Malabo Protocol (Asser Press/ Springer, 2017); Amnesty International, Malabo Protocol: Legal And Institutional Implications of the Merged and Expanded African Court (Amnesty International, 2016); and K Ambos, 'Expanding the Focus of the "African Criminal Court" in WA Schabas et al. (eds), The Ashgate Research Companion to International Criminal Law: Critical Perspectives (Routledge, 2013) 499-529. The Court is empowered to try 'persons' (individuals and legal persons, with the exception of states) for the fol lowing crimes: genocide, crimes against humanity, war crimes, unconstitutional change of government, piracy, terrorism, mercenarism, corruption, money launder ing, trafficking in persons, drugs and hazardous wastes, illicit exploitation of natural resources and aggression.

${ }^{246}$ Malabo Protocol (n 245).

${ }^{247}$ Such as Nuremberg Tribunals, Tokyo Tribunals, ICTY, ICTR, Special Court for Sierra Leone and Lebanon Tribunals. 
in such capacity, or other senior state officials based on their functions, during their tenure of office. ${ }^{248}$

The scope of the above provision is unclear. First, what is meant by 'anybody acting or entitled to act in such capacity'? Is this limited to the deputy head of state or government or does it extend to all ministers and all members of parliament? Second, does Article 46A bis provide both immunity ratione personae (covering all acts, whether in private or official capacity of heads of state or government and ministers of foreign affairs) and immunity ratione materiae (covering state officials acting as such) or only one type of immunity - immunity ratione materiae? Is the phrase 'based on their functions' in Article 46A bis limited to 'other senior state officials' or does it also extend to 'any serving AU Head of State or Government', or 'anybody acting or entitled to act in such capacity'? Third, are serving AU state officials who acquire or maintain power through 'unconstitutional change of government' entitled to immunity before the African Court? ${ }^{249}$ These questions will have to be addressed by the Court.

It is clear nonetheless that the African Court of Justice and Human and Peoples' Rights, when established, will exercise jurisdiction primarily over non-state actors. Article 46A bis above clearly indicates that AU heads of state who adopted the above immunity provision were opposed to criminal justice being applied to them. This is consistent with the AU's claim that under customary international law: 'Heads of state and other senior state officials are granted immunities during their tenure of office'. ${ }^{250}$ According to the AU these immunities apply to proceedings in both 'foreign domestic courts' as well as to 'international tribunals'. ${ }^{251}$ However, this view goes against the position of the International Court of Justice which recognised that state officials may be subject to criminal proceedings before 'certain international criminal courts' or tribunals (as opposed

${ }^{248}$ For a discussion see M Ssenyonjo and S Nakitto, 'The African Court of Justice and Human and Peoples' Rights 'International Criminal Law Section': Promoting Impunity for African Union Heads of State and Senior State Officials?' (2016) 16(1) International Criminal Law Review 71-102. This immunity exception contrasts with the AU's proposal for the establishment of an AU-backed hybrid Court for South Sudan, where no such immunity bar applies and the proposal appears to be modelled on Article 27 of the Rome Statute.

${ }^{249}$ Malabo Protocol (n 245), $28 \mathrm{E}$.

${ }^{250}$ Decision on Africa's Relationship with the ICC, Ext/Assembly/AU/Dec.1 (October 2013) para 9.

${ }^{251}$ See AU Press Release 02/2012. 
to prosecution before courts of foreign states) having jurisdiction in certain instances. ${ }^{252}$

Article $46 \mathrm{~A}$ bis is intended to protect serving AU heads of states and other state officials from being held accountable for potential individual criminal responsibility for the most serious crimes. It will thus not enhance the struggle against impunity for ordering, requesting, encouraging or contributing, in any other manner, to the commission of crimes within the jurisdiction of the ICC by serving senior state officials. Granting immunity to 'any serving AU Head of State or Government', or 'anybody acting or entitled to act in such capacity', and undefined 'other senior state officials' while in office may have the effect of encouraging more AU heads of state to stay longer in power to avoid criminal accountability. In contrast, Article 27 of the Rome Statute provides that 'official capacity as a Head of State or Government... shall in no case exempt a person from criminal responsibility' and that immunities shall not bar the Court from exercising its jurisdiction. ${ }^{253}$ Due to the granting of immunity, relevant cases involving AU state officials would remain admissible before the ICC where it has jurisdiction under Article 17 of the Rome Statute as a consequence of inaction. ${ }^{254}$ This is because the effect of immunity is that no 'case' will be investigated or prosecuted by the African Court (on behalf of any state having jurisdiction) against senior state officials. As a result, cases involving African state officials will remain admissible before the ICC since it will not be possible to argue that the 'same individual and substantially the same conduct' as alleged in the proceedings before the ICC is being investigated or prosecuted before the African Court. ${ }^{255}$

Second, the criminal jurisdiction of the African Court of Justice and Human and Peoples' Rights will only apply to crimes committed after the entry into force of the Court's Protocol and establishment of the Court. 15 ratifications are required for the Protocol to enter into force, but by January 2017 none had been secured for more than two

${ }^{252}$ See Case Concerning the Arrest Warrant of 11 April 2000 (Democratic Republic of the Congo v Belgium), Judgment of 14 February 2002 (2002) ICJ Reports 3, paras 58-61.

253 The Prosecutor v William Samoei Ruto and Joshua Arap Sang, No. ICC-01/0901/11, Decision on Mr Ruto's Request for Excuse from Continuous Presence at Trial, Trial Chamber V, 18 June 2013, para 67.

${ }^{254}$ Katanga et al., ICC-01/04-01/07 OA 8, 25 September 2009, para 75-78.

${ }^{255}$ Muthaura et al., ICC-01/09-01/11 OA, 30 August 2011, para 40. 
years though 9 states had signed the Protocol. ${ }^{256}$ South Africa, Burundi and The Gambia had not signed or ratified the Protocol. This compares very poorly to the Rome Statute which had 60 ratifications within 2 years of being open for signature and ratification. Given the reluctance of African states to accept jurisdiction of a regional court, it is likely to take several decades for most African states to ratify the Protocol. For example, almost two decades after the adoption of the Protocol to the African Charter on Human and People's Rights on the Establishment of an African Court on Human and People's Rights, ${ }^{257}$ with human rights jurisdiction only, it had been ratified by only 30 Member states ${ }^{258}$ and only 8 had deposited the optional declaration under Article 34(6) thereof allowing individuals and Non-Governmental organisations (NGOs) with observer status before the African Commission on Human and Peoples' Rights direct access to the Court. ${ }^{259}$

Finally even if the Protocol enters into force, ratified by all withdrawing states and Article 46A bis is amended to remove immunity, there are still other legitimate concerns about the likely effectiveness of the African Court. These include the very wide jurisdiction of the Court, the poor structure of the Court, human resource capacity, and the capacity of African states to meet the financial needs of such a Court. ${ }^{260}$

\section{CONCLUSION}

While signing and ratifying the Rome Statute is a voluntary and a sovereign decision of every state, state withdrawals from the Rome Statute undermine the global movement towards greater accountability to put an end to impunity for the perpetrators of the most

${ }^{256}$ The Protocol had been signed by Benin, Chad, Congo, Ghana, Guinea-Bissau, Kenya, Mauritania, Sierra Leone, and Sao Tomé \& Principe.

${ }^{257}$ Adopted 9 June 1998, entered into force 25 January 2004, OAU Doc. OAU/ LEG/EXP/AFCHPR/PROT (III).

258 These were Algeria, Benin, Burkina Faso, Burundi, Cameroon, Chad, Congo, Côte d'Ivoire, Comoros, Gabon, The Gambia; Ghana, Kenya, Libya, Lesotho, Malawi, Mali, Mauritania, Mauritius, Mozambique, Niger, Nigeria, Uganda, Rwanda, Sahrawi Arab Democratic Republic, Senegal, South Africa, Tanzania, Togo and Tunisia.

${ }^{259}$ These were Benin, Burkina Faso, Côte d'Ivoire, Ghana, Malawi, Mali and the United Republic of Tanzania.

${ }^{260}$ Ssenyonjo and Nakitto (n 248). 
serious crimes (genocide, crimes against humanity, war crimes and aggression) and a ruled-based international order. Withdrawals from the Rome Statute limit the Court's jurisdictional reach and its ability to provide justice to the victims of such crimes and contribute to the prevention of future atrocities. Withdrawing from the Rome Statute without a credible alternative mechanism (national or regional judicial systems) in place to investigate and prosecute international crimes without any distinction based on official capacity shields state officials who commit crimes from accountability. It also undermines the AU's 'condemnation and rejection of impunity' in respect of grave crimes, in particular genocide, war crimes, and crimes against humanity. ${ }^{261} \mathrm{~A}$ number of measures may be taken to prevent further future justifications of withdrawals by African states from the Rome Statute.

First, the ICC mainly through the Assembly of States Parties must engage in a meaningful and constructive dialogue with the reasons 'good' or 'bad' - advanced by withdrawing states, such as those advanced by South Africa, to justify withdrawal. To enhance the credibility of the ICC and complementarity with the state parties, the ICC Prosecutor, President of the Court and President of the Assembly of State Parties should conduct extensive awareness campaigns. While more outreach would require more resources, it is helpful to counteract media, political and diplomatic (mis)information campaigns used by states to undermine the ICC. Such campaigns should be done in cooperation with state parties, UN bodies, regional organisations and relevant domestic actors (such as the judiciary, prosecutors, lawyers, victims, and civil society) on the ICC's work at the national, sub-regional, regional and international levels.

Second, the Prosecutor must demonstrate that crimes within the jurisdiction of the Court are investigated objectively wherever such crimes are committed. In particular, the Prosecutor must ensure that all crimes within the jurisdiction of the Court committed in appropriate non-African situations are pursued beyond preliminary investigations. These include crimes against humanity and war crimes committed by parties to the conflict - the Georgian armed forces, the South Ossetian forces, and the Russian armed forces - in the context of an international armed conflict in and around South Ossetia, Georgia between 1 July and 10 October $2008^{262}$; war crimes com-

\footnotetext{
${ }^{261}$ Constitutive Act of the African Union, 11 July 2000, 4(o) and 4(h).

${ }^{262}$ See Pre-Trial Chamber 1, Situation in Georgia: Decision on the Prosecutor's Request for Authorization of an Investigation, No. ICC-01/15, 27 January 2016.
} 
mitted by members of the US armed forces and the US Central Intelligence Agency in Afghanistan ${ }^{263}$; and crimes against humanity of torture, deportation, persecution, and other inhumane acts committed against asylum seekers including women and children by Australian government officials and their private contractors. ${ }^{264}$

Third, it is proposed that instead of withdrawing from the Rome Statute, concerned African states could invoke Article 98(2) of the Rome Statute which provides that:

The Court may not proceed with a request for surrender which would require the requested State to act inconsistently with its obligations under international agreements pursuant to which the consent of a sending State is required to surrender a person of that State to the Court, unless the Court can first obtain the cooperation of the sending State for the giving of consent for the surrender.

There are different views about the above provision. One view is that the above article was intended to protect the status of forces agreements in existence prior to signature of the Rome Statute. ${ }^{265}$ On this basis it is argued that Article 98(2) 'only refers to existing agreements' which means 'agreements concluded by a State party before the latter's signature of the Statute'. ${ }^{266}$ Accordingly it is argued that a state intentionally negotiating an Article 98(2) designed to purposefully avoid its obligations to arrest and surrender a person sought by the Court would be violating the basic principle not to defeat the object and purpose of a treaty. ${ }^{267}$ Another view is that Article 98(2) allows agreements negotiated and ratified subsequently. ${ }^{268}$ Under the above provision, African states can negotiate a multilateral treaty among themselves to prohibit the arrest and surrender of any national of a non-party state including head of state or senior state official to the ICC provided any such individual is 'indispensable' to the pursuit of a

${ }^{263}$ Report on Preliminary Examination Activities 2016 (n 65), para 211.

${ }^{264}$ See The Situation in Nauru and Manus Island: Liability for Crimes against Humanity in the Detention of Refugees and Asylum Seekers (February 2017), https://www.scribd.com/document/339213633/Communication-made-to-InternationalCriminal-Court-requesting-investigation-of-Australia-and-corporate-contractors.

${ }^{265}$ See C Kreß and K Prost, 'Article 98: Cooperation with Respect to Waiver of Immunity and Consent to Surrender' in Triffterer and Ambos (n 7), 2117-2146, at 2142-2146.

266 Ibid., at 2146.

${ }^{267}$ Ibid.; Vienna Convention on the Law of Treaties (n 189), Art 18.

${ }^{268}$ D Scheffer, 'Article 98(2) of the Rome Statute: America's Original Intent' (2005) 3(2) Journal of International Criminal Justice 333, at 336. 
peace settlement for an ongoing conflict in Africa. ${ }^{269}$ Once such a treaty enters into force, the Court is obliged to first obtain the consent of the 'sending State' for the surrender of a person wanted by the ICC.

Fourth, since the ICC is not a substitute for national justice systems but it is rather 'complementary' to them, ${ }^{270}$ it is imperative that states develop effective national (or regional) criminal justice systems to genuinely investigate and prosecute international crimes. African states that are unable to carry out prompt, impartial, thorough and transparent investigations and/or prosecutions of crimes within the jurisdiction of the ICC must enhance their domestic institutional (investigative and judicial) capacity. This should include seeking assistance from the ICC Prosecutor's office, conducting legal reform by enacting and enforcing ICC national implementing legislation integrating provisions of the Rome Statute in domestic law including crimes within the Court's jurisdiction and granting authority to national prosecuting authority to refer situations to the ICC, cooperation with the Court and enforcement/execution of sentences, enhancing national capacity-building by training investigators, prosecutors and judges and infrastructure investment in the court system.

Fifth, the Rome Statute does not indicate whether a notification of withdrawal can itself be withdrawn at any time before the withdrawal becomes effective. In principle, it will be in the interest of victims of international crimes for Burundi to follow the example of The Gambia and South Africa to withdraw their withdrawal notifications and for other ICC state parties to refrain from withdrawing from the Rome Statute in the future. As noted above, the expanded jurisdiction of the African Court does not affect the jurisdiction of the ICC particularly over serving state officials who may enjoy immunity under Article 46 bis.

Finally, notifications of withdrawal from treaties must be consistent with relevant domestic law. ${ }^{271}$ As confirmed by the South African High Court, South Africa's notification of withdrawal, without prior parliamentary approval, was unconstitutional, invalid and must

${ }^{269}$ D Scheffer, 'More Options for Africa under the Rome Statute' Just Security, 19 November 2016, https://www.justsecurity.org/34669/options-africa-rome-statute-in ternational-criminal-court-scheffer/\#more-34669.

${ }^{270}$ Rome Statute (n 1), Preamble para 10, Arts 1 and 17.

${ }^{271}$ See $R$ (Miller) v The Secretary of State for Exiting the European Union [2016] EWHC 2768 (Admin); $R$ (on the application of Miller and another) $v$ Secretary of State for Exiting the European Union [2017] UKSC 5. 
be revoked. ${ }^{272}$ Therefore, the executive must wait for parliament to successfully repeal the ICC domestic implementing legislation before submitting a valid notification of withdrawal to restart the 12-month withdrawal period under Article 127(1) of the Rome Statute. This period could be used by South Africa to reconsider the wisdom or desirability of withdrawing from the Rome Statute and to engage in constructive diplomatic dialogue and judicial mechanisms to address issues raised in Section II above.

\section{OPEN ACCESS}

This article is distributed under the terms of the Creative Commons Attribution 4.0 International License (http://creativecommons.org/ licenses/by/4.0/), which permits unrestricted use, distribution, and reproduction in any medium, provided you give appropriate credit to the original author(s) and the source, provide a link to the Creative Commons license, and indicate if changes were made.

${ }^{272}$ Democratic Alliance v Minister of International Relations and Cooperation and Others, Case No 83145/2016 (n 16). 